\title{
Fiscal Year 1997 Final Report for Task Plan SR-16WT-31 Task B, Vitrification of Ion Exchange Material
}

by

D. Ferrara

Westinghouse Savannah River Company

Savannah River Site

Aiken, South Carolina 29808

M. K. Andrews

P. J. Workman

J. R. Harbour

T. L. Fellinger

D. T. Herman

K. M. Marshall

DOE Contract No. DE-AC09-96SR18500

MASTER

This paper was prepared in connection with work done under the above contract number with the U. S.

Department of Energy. By acceptance of this paper, the publisher and/or recipient acknowledges the U.S. Government's right to retain a nonexclusive, royalty-free license in and to any copyright covering this paper, along with the right to reproduce and to authorize others to reproduce all or part of the copyrighted paperf 


\section{DISCLAIMER}

This report was prepared as an account of work sponsored by an agency of the United States Government. Neither the United States Government nor any agency thereof, nor any of their employees, makes any warranty, express or implied, or assumes any legal liability or responsibility for the accuracy, completeness, or usefulness of any information, apparatus, product, or process disclosed, or represents that its use would not infringe privately owned rights. Reference herein to any specific commercial product, process, or service by trade name, trademark, manufacturer, or otherwise does not necessarily constitute or imply its endorsement, recommendation, or favoring by the United States Government or any agency thereof. The views and opinions of authors expressed herein do not necessarily state or reflect those of the United States Government or any agency thereof.

This report has been reproduced directly from the best available copy.

Available to DOE and DOE contractors from the Office of Scientific and Technical Information, P.O. Box 62, Oak Ridge, TN 37831; prices available from (615) 576-8401.

Available to the public from the National Technical Information Service, U.S. Department of Commerce, 5285 Port Royal Road, Springfield, VA 22161. 


\section{DISCLAIMER}

Portions of this document may be illegible electronic image products. Images are produced from the best available original document. 


\section{Distribution List}

E. W. Holtzscheiter, 773-A

B. N. Attaway, 773-A

B. C. Ha, 773-43A

D. A. Crowley, 773-43A

C. R. Goetzman, 773-A

L. M. Papachoudo, 773-A

M. K. Andrews, 773-A

J. R. Harbour, 773-43A

T. L. Fellinger, 773-A

D. T. Herman, 773-41A

K. M. Marshall, 773-43A

P. J. Workman, 773-A 
Keywords: Crystalline Silicotitanate, Cesium, Ion Exchange, Coupled, Vitrification

September 30, 1997

Fiscal Year 1997 Final Report for Task Plan SR-16WT-31

Task B, Vitrification of Ion Exchange Material (U)

Principle Investigator:

\author{
Daro Ferrara \\ Westinghouse Savannah River Company \\ Savannah River Technology Center \\ Aiken, South Carolina
}

Contributors:

M. K. Andrews, J. R. Harbour, T. L. Fellinger, D. T. Herman, K. M. Marshall, and P. J. Workman

Westinghouse Savannah River Company

Savannah River Technology Center

Aiken, South Carolina

In Fiscal Year 1997, the Department of Energy Tanks Focus Area (TFA) funded the Savannah River Technology Center (SRTC) to develop and demonstrate the vitrification of a CST ion exchange material loaded with radioactive cesium from one of the Melton Valley Storage Tanks at the Oak Ridge National Laboratory (ORNL). SRTC developed a patent-pending glass formulation that can be used to vitrify CST sorbent producing a quality borosilicate glass waste form. SRTC demonstrated this formulation by vitrifying the radioactive CST in the SRTC shielded cells melter.

In addition to the formulation developed for vitrification of the "CST-only" glass waste form, SRTC also developed formulations for vitrification of CST coupled with High-Level Waste (HLW) sludges. A Defense Waste Processing Facility (DWPF) coupled feed formulation has been developed with up to 10 weight percent CST and 28 weight percent DWPF sludge oxides. A coupled Hanford formulation has also been developed for producing quality glass waste forms with up to 10 weight percent CST and 45 weight percent Hanford sludge oxides.

\title{
Significant Accomplishments
}

The significant accomplishments of this project were the

- development of CST-only glass formulations incorporating up to 65 weight-percent CST

- development of techniques for delivering a slurry or dry feed to a joule-heated melter

- demonstration of a CST-only glass formulation in a continuous melter operation

- demonstration of compliance with the Nevada Test Site (NTS) Waste Acceptance Criteria (WAC)

- development of CST-sludge glass formulations incorporating up to 10 weight percent CST and 28 weight percent DWPF sludges oxides

- demonstration of CST-sludge glass formulations using radioactive sludge and radioactive CST

- development of CST-sludge glass formulations incorporating up to 10 weight percent CST and 45 weight percent Hanford sludge 
Milestones

All commitments made to the TFA have been met as indicated by the associated milestones. Milestones and the month in which they were completed were

- B1. Initiate Immobilization of CST in Glass (completed 8/97)

a2. Demonstrate that Sludge-CST Glass Satisfied PC Specs in WAPS (completed 9/97)

- B3. Determine Process Parameters of Sludge-CST Glass (completed 8/97)

m4. Demonstrate that CST-Only Glass Satisfied PC Specs in WAPS (completed 9/97)

- B5. Determine Process Parameters of CST-Only Glass (completed 9/97)

\section{$\underline{\text { Reports }}$}

The resuits for Task B of Task Plan SR-16WT-31 have been documented in reports that have been included as attachments. The following is a summary of the attachments from the CST vitrification project.

\section{CST-Only Glass Formulations}

Formulations were developed for vitrification of CST alone, i.e. no other waste stream was included in the glass. The resulting formulations were demonstrated by vitrification of the radioactive CST from ORNL in the SRTC shielded cells joule-heated melter. The resulting glass was shown to meet the WAC for a Low-Level Waste disposal site. Prior to this demonstration, the material from previous demonstrations was flushed from the melter. After this demonstration, the CST material was flushed from the melter to prepare for future demonstrations. The following reports describe the results from the CST-only portion of the task:

\section{K. Andrews and J. R. Harbour, "Use of the Existing Shielded Cells Melter for CST Vitrification (U),"} WSRC-RP-96-593, Rev. 0 (1996).

This report presents the requirements for displacing the HLW glass that was in the melter prior to the initiation of the CST campaign. It also identifies the risks associated with using the existing melter. The report has been included as Attachment 1 .

M. K. Andrews, "Glass Formulation Development and Testing for the Vitrification of Cesium-Loaded Crystalline Silicotitanate (CST)," conference proceedings from the Air and Waste Management Association Annual Meeting (1997). WSRC-M. $7 . \infty 4$

Prior to the radioactive demonstration, a glass formulation that would produce a durable and processable glass had to be developed. The main concern was the formation of crystals as a result of the titanium dioxide content that would have to be present in the glass in order to achieve reasonable CST loadings. A formulation was developed that incorporated up to 65 weight percent CST without the formation of crystals. During melter operation, it was desirable to be conservative and operate within a safety factor. Therefore, CST loadings between 50 and 60 weight percent were the focus of the glass formulation development. Attachment 2 presents the glass formulation results in more detail.

M. K. Andrews, T. L. Fellinger, D. M. Ferrara, J. R. Harbour, and D. T. Herman, "Vitrification of CesiumLoaded Crystalline Silicotitanate (CST) in the Shielded Cells Melter (U)," WSRC-TR-97-00314 (1997).

To demonstrate that the glass formulation described in Attachment 2 was compatible with melter technology, the developed formulation was used to produce a borosilicate glass waste form using the radioactive CST provided by ORNL. This demonstration was performed in the SRTC shielded cells research melter. A borosilicate glass containing 50 to 55 weight percent CST was produced in this 
demonstration. This demonstration indicated that the formulation could be used to vitrify CST in a melter system. A report on this demonstration has been included as Attachment 3.

K. M. Marshall, T. L. Fellinger, and J. R. Harbour, "Final Flush of the Shielded Cells Melter (U)." WSRCTR-97-00316 (1997).

Upon completion of the CST-only demonstration, the radioactive CST material was flushed from the melter using a DWPF frit. The goal of the flush was to bring the titanium concentration in the melter to levels that would be compatible with subsequent demonstrations in the SRTC shielded cells. This was accomplished by flushing the melter with approximately 40 kilograms of frit. A report on the melter flush has been included as Attachment 4.

J. R. Harbour and M. K. Andrews, "Compliance with the Nevada Test Site's Waste Acceptance Criteria for Vitrified Cesium-Loaded Crystalline Silicotitanate (CST)," conference proceedings for the Air and Waste Management Association Annual Meeting, (1997).

Because the vitrified CST produced in these studies is Low-Level Waste (LLW), the appropriate off-site disposal facility would be a LLW disposal site. Although waste generated during this demonstration is being disposed of at SRS, future users of this technology will need to ensure compliance with the Waste Acceptance Criteria (WAC) of a LLW repository. The material produced during the demonstration will meet these WAC; however at higher cesium-loadings, "greater-than-Class C" limits may restrict the disposal options. A report detailing the compliance of the glass form to the NTS WAC has been included as Attachment 5.

\section{CST-Sludge Glass Formulations}

Formulations were developed for vitrification of CST with HLW sludges from DWPF and Hanford. The resulting CST-DWPF sludge formulations were demonstrated on a crucible scale by vitrification of the radioactive CST from ORNL and radioactive DWPF sludge. The resulting CST-Hanford sludge formulations were demonstrated by vitrification of nonradioactive CST and nonradioactive Hanford sludge simulants. The following reports describe the CST-HLW sludge portion of the task:

M. K. Andrews and J. R. Harbour, "Glass Formulation Requirements for DWPF Coupled Operations Using Crystalline Silicotitanates (U),"WSRC-TR-97-0004 (1997).

The technical approach taken in developing the CST-DWPF HLW sludge formulations was described in a basis paper. The report describes the bases for the ranges of CST and HLW sludge loadings used in the glass development. These loadings were based on the concentrations needed to produce a glass waste form with the HLW loading and the cesium loading similar to those expected in the DWPF during coupled operations. The report has been included as Attachment 6 .

M. K. Andrews and P. J. Workman, "Glass Formulation Development and Testing for the Vitrification of DWPF HLW Sludge Coupled with Crystalline Silicotitante (CST) (U)," WSRC-TR-97-00312 (1997).

A glass formulation was developed using nonradioactive sludge and unloaded CST. The resulting glass was more durable than the HLW Environmental Assessment glass, thus meeting the product specifications of the Waste Acceptance Product Specifications (WAPS). The glass also had viscosity and liquidus properties within the acceptable processing ranges. The radioactive demonstration of this formulation using Tank 51 sludge and Cs-loaded CST successfully incorporated 28 weight percent sludge oxides and 5 weight percent CST. Attachment 7 details the results of this testing. 
M. K. Andrews and J. R. Harbour, "Glass Formulation Requirements for Hanford Coupled Operations Using Crystalline Silicotitanate (CST) (U)," WSRC-RP-97-0265, (1997).

The technical approach taken in developing the CST-Hanford HLW sludge formulations was described in a basis paper. The report describes the bases for the ranges of CST and HLW sludge loadings used in glass development. These loadings were based on the concentrations needed to produce a glass waste form with the HLW loading and the cesium loading expected in processes that are currently being developed for vitrification of Hanford tank waste. The report has been included as Attachment 8 .

\section{Acknowledgments}

The author is very thankful for the talents and the dedication of the other members of the project team. Their perseverance, skills, and insight made this project possible. The other team members were Mary Andrews, John Harbour, Terri Fellinger, David Herman, Kathy Marshall, and Bao Ha.

In addition, to the team members, a number of other individuals assumed ownership of portions of this project. Phyllis Workman was key to the development of the formulations. Sherry Vissage and Debbie Marsh also supplied key support throughout this project.

Finally, none of the radioactive work could have been completed without the talents of the Shielded Cells Operations technical support. The project was a success because of the ties this entire organization felt to the CST vitrification project. 


\section{Attachment 1.}

M. K. Andrews and J. R. Harbour, "Use of the Existing Shielded Cells Melter for CST Vitrification (U)," WSRC-RP-96-593, Rev. 0 (1996). 
WESTINGHOUSE SAVANNAH RIVER COMPANY

SAVANNAH RIVER TECHNOLOGY CENTER

WSRC-RP-96-593

\title{
USE OF THE EXISTINGSHIELDED CELLS MELTER FOR CST VITRIFICATION (U)
}

\author{
J. R. Harbour and M. K. Andrews \\ Westinghouse Savannah River Company \\ Aiken, S. C. 29808
}

\section{INTRODUCTION}

Oak Ridge National Laboratory (ORNL) and SRTC are participating in a joint project in which supernate waste from the Melton Valley Storage Tanks at Oak Ridge (OR) will be treated by passage through a crystalline silicotitanate (CST) ion exchange medium'. The CST was designed to sorb cesium, the primary radionuclide (Cs-137) in the supernate of the Melton Valley tanks. A smaller amount of strontium will also be scrbed. The loaded sorbent will then be shipped to SRTC where it will be mixed with glass formers and fed as an aqueous slurry to a joule-heated melter within the SRTC Shielded Cells. The molten glass $\left(\sim 1150^{\circ} \mathrm{C}\right)$ will be poured into $500 \mathrm{~mL}$ stainless steel beakers which in turn will be placed in 30 gallon drums for shipment to and disposal at the Nevada Test Site (NTS). This paper focuses on the requirements necessary for disposal of the vitrified CST at NTS. This work is funded by the Tank Focus Area with additional funding from EM-30 at OR.

A reduction in scope is currently under consideration for the vitrification demonstration. This change in scope would reduce the number of drums sent to SRTC from seven to one. The amount of CST that would be vitrified in this case is $\sim 38 \mathrm{Kg}$. If this scope change is realized, then the vitrified CST in the $500 \mathrm{~mL}$ beakers will be disposed of at Savannah River Site (SRS). The results presented in this report will also be useful if the vitrified waste remains at SRS.

The Shielded Cells Melter currently contains glass produced during a 1995 DWPF demonstration campaign. That campaign incorporated radioactive Tank 51 sludge into a DWPF bórosilicate glass. The Tank 51 campaign in the Shielded Cells Melter was preceded with a flushing of the melter using non-radioactive glass. This flushing was preceded by a different Tank 51 campaign again using borosilicate glass. The 1995 Tank 51 campaign and the melter flushing each used less than one melter volume of material. This implies that the glass currently in the melter is a composite of glass from both Tank 51 campaigns and from melter flushing. If the vitrified CST will be shipped to NTS, the radioactive glass currently in the melter must be removed prior to the CST vitrification demonstration in order to avoid commingling of the waste.

This report (1) estimates the concentrations of the radioactive and RCRA hazardous components of the glass now contained in the Shielded Cells melter, (2) presents the requirements for displacing the existing glass with non-radioactive glass to ensure that radionuclide and RCRA metal levels are below the Waste Acceptance Criteria (WAC) limits set by NTS, (3) identifies the risks associated with a melter flushing strategy and (4) considers the alternative of installing a new melter within the Shielded Cells. 


\section{STATUS OF MELTER}

The melter within the Shielded Cells contains $\sim 10 \mathrm{Kg}$ of molten glass at $\sim 1150^{\circ} \mathrm{C}$. Between campaigns the normal operating procedure is to maintain the melter at $1050^{\circ} \mathrm{C}$ with a full load of glass.

Radioactive Tank 51 sludge ${ }^{2}$ was used in the last melter campaign, which produced $9.1 \mathrm{Kg}$ of glass. This Tank 51 campaign was preceded with a $6.95 \mathrm{Kg}$ flushing of the melter using nonradioactive glass frit. This flushing was preceded by an earlier Tank 51 campaign, using $~ 31$ $\mathrm{Kg}$ of borosilicate glass. Since the nonradioactive glass frit did not contain radionuclides or RCRA metals, the only source for introduction of these constituents is Tank 51 sludge.

Material flow through the melter can range from plug flow to a continuously stirred tank flow. For this report the more conservative material flow, continuously stirred tank flow, was used to estimate the current constituents within the melter. This approach implies that the waste is composed of $\sim 80 \%$ radioactive waste glass (containing $\sim 25 \mathrm{wt} \%$ Tank 51 sludge) and $\sim 20 \%$ nonradioactive glass. A conservative approach was taken by assuming that the melter currently contains $100 \%$ radioactive waste glass with a $25 \mathrm{wt} \%$ loading of Tank 51 sludge.

\section{RADIONUCLIDE INVENTORY}

The results of radionuclide analyses are presented in two groups. The first group lists transuranic waste, and the second lists the remaining radionuclides.

\section{Group 1. Transuranics.}

The NTS definition of transuranic waste is:

TRANSURANIC (TRU) WASTE: Radioactive waste containing alpha emitting radionuclides having an atomic number greater than 92 , and half-lives greater than 20 years, in concentrations greater than $100 \mathrm{nCi} / \mathrm{g}$.

Table 1 lists the transuranics (including $\mathrm{Cm}-244$, even though it has a half life of 18.1 years) present in washed Tank 51 sludge. $^{2}$ This Table also contains the concentrations of transuranics present in the waste glass (assuming $25 \mathrm{wt} \%$ Tank 51 sludge).

TABLE 1 - Alpha Emitting Transuranic Concentrations Present in Tank 51 Sludge (washed and dried) and in the Borosilicate Glass

\begin{tabular}{|c|c|c|c|}
\hline Radionuclide & $\begin{array}{c}\text { Half-Life } \\
\text { years }\end{array}$ & $\begin{array}{c}\text { Tank } 51 \\
\mathrm{nCi} / \mathrm{g}\end{array}$ & $\begin{array}{l}\text { Glass } \\
\mathrm{nCi} / \mathrm{g}\end{array}$ \\
\hline $\mathrm{Np}-237$ & $2.1 \mathrm{E}+06$ & $1.4 \mathrm{E}+01$ & $3.5 \mathrm{E}+00$ \\
\hline $\mathrm{Pu}-238$ & $8.8 \mathrm{E}+01$ & $1.4 \mathrm{E}+05$ & $3.5 \mathrm{E}+04$ \\
\hline$\longdiv { \mathrm { Pu } - 2 3 9 }$ & $2.4 \mathrm{E}+04$ & $6.9 \mathrm{E}+03$ & $1.7 \mathrm{E}+03$ \\
\hline$\overline{\mathrm{Pu}-240}$ & $6.6 \mathrm{E}+03$ & $1.8 \mathrm{E}+03$ & $4.5 \mathrm{E}+02$ \\
\hline $\mathrm{Pu}-242$ & $3.7 E+05$ & $1.6 \mathrm{E}+00$ & $4.0 \mathrm{E}-01$ \\
\hline Am-241 & $4.3 \mathrm{E}+02$ & $6.2 \mathrm{E}+03$ & $1.6 \mathrm{E}+03$ \\
\hline Am-243 & $7.4 \mathrm{E}+03$ & $3.8 \mathrm{E}+01$ & $1.0 \mathrm{E}+01$ \\
\hline $\mathrm{Cm}-244$ & 1.8.E+01 & $1.2 \mathrm{E}+04$ & $3.0 \mathrm{E}+03$ \\
\hline
\end{tabular}


The total alpha for transuranics in the glass listed is $\sim 42,000 \mathrm{nCi} / \mathrm{g}$. The NT⿱S requirement limits the TRU component of the waste to less than $100 \mathrm{nCi} / \mathrm{g}$. In order to ensure that this limit is not exceeded, an operational limit of $\sim 50 \mathrm{nCi} / \mathrm{g}$ is proposed. To achieve the proposed operational limit, the glass in the melter must be displaced by the nonradioactive frit such that the TRU radionuclide concentration is reduced by a factor of 840 . That is, $99.88 \%$ of the radionuclides must be removed prior to start of the CST vitrification demonstration. A conservative approach is to require a reduction of the TRU components by a factor of 1000 .

\section{Group 2. Other Radionuclides.}

The concentrations for the remaining radionuclides ${ }^{2}$ in the washed Tank 51 sludge and in the glass are presented in Table 2. (The radionuclide content in $\mathrm{Ci} / \mathrm{Kg}$ was converted to $\mathrm{Ci} / \mathrm{m}^{3}$ using a glass density of $2.7 \mathrm{~g} / \mathrm{cc}$.) These radionuclides emit primarily beta-gamma radiation. For purposes of the calculations, it is conservatively estimated $100 \%$ of the elements listed here are present in the glass (at 25\% waste loading) within the Shielded Cells Melter.

TABLE 2 - Beta-Gamma Emitting Radionuclide Concentrations in Washed Tank 51 Sludge and in DWPF Glass

\begin{tabular}{|c|c|c|c|}
\hline & Sludge & Glass & $\begin{array}{r}\text { Glass } \\
3\end{array}$ \\
\hline Radionuclide & $\mathrm{Ci} / \mathrm{kg}$ & $\mathrm{Ci} / \mathrm{kg}$ & $\mathrm{Ci} / \mathrm{m}^{3}$ \\
\hline $\mathrm{Ni}-59$ & $5.40 \mathrm{E}-05$ & $1.40 \mathrm{E}-05$ & $2.70 \mathrm{E}-03$ \\
\hline $\mathrm{Ni}-63$ & $9.60 \mathrm{E}-03$ & $2.40 \mathrm{E}-03$ & $6.50 \mathrm{E}-00$ \\
\hline Se-79 & $2.20 \mathrm{E}-05$ & $5.00 \mathrm{E}-06$ & $1.40 \mathrm{E}-01$ \\
\hline Sr-90 & $6.40 \mathrm{E}-01$ & $1.60 \mathrm{E}-01$ & $4.32 \mathrm{E}+02$ \\
\hline $\mathrm{Zr}-93$ & $5.40 \mathrm{E}-05$ & $1.35 \mathrm{E}-05$ & $3.65 \mathrm{E}-02$ \\
\hline $\mathrm{Nb}-93 \mathrm{~m}$ & $3.10 \mathrm{E}-05$ & $7.75 \mathrm{E}-06$ & $2.10 \mathrm{E}-02$ \\
\hline Tc-99 & $2.20 \mathrm{E}-04$ & $5.50 \mathrm{E}-05$ & $1.50 \mathrm{E}-01$ \\
\hline Pd-107 & $3.80 \mathrm{E}-07$ & 9.50E-08 & $2.60 \mathrm{E}-04$ \\
\hline Sn-126 & $6.50 \mathrm{E}-06$ & $1.63 \mathrm{E}-06$ & $4.40 \mathrm{E}-03$ \\
\hline Cs-135 & $2.50 \mathrm{E}-07$ & $6.25 \mathrm{E}-08$ & $1.70 \mathrm{E}-04$ \\
\hline Cs-137 & $6.30 \mathrm{E}-02$ & $1.60 \mathrm{E}-02$ & $4.32 \mathrm{E}+01$ \\
\hline $\mathrm{Sm}-151$ & $1.20 \mathrm{E}-02$ & $3.00 \mathrm{E}-03$ & $8.10 \mathrm{E}+00$ \\
\hline Th-230 & $4.10 \mathrm{E}-08$ & $1.03 \mathrm{E}-08$ & $2.80 \mathrm{E}-05$ \\
\hline $\mathrm{U}-234$ & $2.50 \mathrm{E}-05$ & $6.25 \mathrm{E}-06$ & $1.70 \mathrm{E}-02$ \\
\hline $\mathrm{U}-238$ & $1.10 \mathrm{E}-05$ & $2.75 \mathrm{E}-06$ & $7.40 \mathrm{E}-03$ \\
\hline
\end{tabular}

The contribution of the beta-gamma emitters present in the Tank 51 glass to the total radioactivity of the CST glass will be small. The removal of $99.9 \%$ of the radionuclides (as a result of the 1000 fold reduction for TRU components) would leave $\sim 0.4 \mathrm{Ci} / \mathrm{m}^{3}$ of Sr-90, the major radionuclide. This value is insignificant relative to the Class $\mathrm{C}$ limit of $4600 \mathrm{Ci} / \mathrm{m}^{3}$.

\section{RCRA METAL CONCENTRATIONS}

The glass within the melter contains RCRA metals from the Tank 51 sludge. ${ }^{2}$ Displacement of the current waste glass with a characteristically non-hazardous (from a RCRA point of view) glass frit will reduce the RCRA metals. The estimated RCRA metal concentrations currently in 
the melter are listed in Table 3. (As with the radionuclides, an assumption was made that the melter contains waste glass with a 25 wt\% loading of Tank 51 sludge). These values were obtained by dissolution and analysis of the vitrified Tank 51 SME product.

TABLE 3 - RCRA Metals Present in the SME Product for the 1995 Washed Tank 51 Sludge Campaign

Metal
\begin{tabular}{|l|c|c|c|}
\multicolumn{2}{c}{$\begin{array}{c}\text { Concentration in Glass } \\
\text { wt } \%\end{array}$} & $\begin{array}{c}\text { Regulatory } \\
\text { Limit (ppm) }\end{array}$ \\
\hline Barium & 0.012 & 120 & 100 \\
\hline Cadmium & 0.037 & 370 & 1 \\
\hline Chromium & 0.196 & 1960 & 5 \\
\hline Mercury & 0 & 0 & 0.2 \\
\hline Silver & 0 & 0 & 5 \\
\hline Lead & 0.05 & 500 & 5 \\
\hline
\end{tabular}

The glass in the melter must be displaced with a non-radioactive, RCRA metal-free glass, such that the worst case metal (chromium) is reduced below the regulatory limit of $5 \mathrm{ppm}$. This will lead to a new glass within the melter which is characteristically non-hazardous (RCRA). To reach the $5 \mathrm{ppm}$ level, the displacement with frit must reduce the level of chromium by a factor of 392. In order to ensure that this limit is not exceeded, an operational limit of $2.5 \mathrm{ppm}$ is proposed. This requires that the factor of 392 be doubled to 784 . Therefore, a reduction by a factor of 1000 (path forward for the transuranics) will reduce the RCRA metal levels below the threshold values of characteristically házardous materials.

\section{OVERALL DISPLACEMENT}

The displacement of the glass currently in the melter by a new nonradioactive glass frit must reduce radionuclides and RCRA metals to levels that meet the NTS WAC if the vitrified CS $\Gamma$ will be shipped to NTS. To achieve this, both the transuranics and RCRA metals mist be reduced to concentrations that are approximately 1000 times less than currently in the glass within the melter. The value of 1000 , although conservative, will be used in the discussions that follow.

\section{MELTER FLUSHING}

Glass frit can be fed to the melter to displace the existing waste. The amount of frit that must be introduced and processed depends upon the mechanism of mixing within the melter. If the two extremes of mixing are plug flow and continuously stirred tank flow, then the continuously stirred tank model is more conservative. If one melter turnover (defined as the melter capacity, which in this case is $\sim 10 \mathrm{~kg}$ ) displaces $50 \%$ of the radionuclides and RCRA metals, then 10 melter turnovers will be required to reduce the radionuclides and RCRA metals to acceptable levels. The actual displacement by one melter volume is greater than $60 \%$ for continuously stirred tank mixing. Therefore, the $50 \%$ assumption can be considered conservative. 
A potential risk with flushing is that regions within the melter where convection and mixing may be slower (including the wall/glass interface) could prolong the release of radionuclides and RCRA metals. If dried slurry/glass adheres either to the refractory above the molten glass line, the melter lid, or the electrodes, there is also the possibility that pieces of this glass or dried slurry could break free from these locations and enter the melt pool.

An estimate has been made for the amount of waste glass (containing 25 wt $\%$ Tank 51 sludge) which must be introduced into the melt to cause radionuclides or RCRA metal limits to be exceeded. Using the concentration level of Pu-238 in the glass, 25 grams of Tank 51 containing glass; which if thoroughly and instantly mixed with the melt pooi, would cause the entire pool to reach the TRU limit of $100 \mathrm{nCi} / \mathrm{g}$. Since the density of glass is $\sim 2.5$, this corresponds to $\sim 10 \mathrm{~mL}$ of glass.

The type of non-radioactive glass used to flush the melter is also important. Certain glasses may more readily remove or displace the current glass in the melter. However, the glass in the melter must be compatible with the feed introduced during the vitrification of the CST sorbent. The preferred way of accomplishing this is to use a frit that is identical to the expected CST waste glass formulation (without radionuclides).

During the process of flushing the melter, samples will be taken from the glass pour stream. These samples will be dissolved and analyzed for RCRA metals and radionuclides to determine the efficiency of the flushing. The actual number of melter turnovers required will not be based on the material flow models, but on the analytical results of the glass samples.

\section{INSTALLATION OF A NEW MELTER}

An alternative to the approach of melter flushing is to install a new melter in the Shielded Cells. This is a non-trivial job which would require additional time. The existing melter would still need to be flushed with nonradioactive material and then decoupled from the off-gas system, removed, and dispositioned. A new melter (one new melter has already been fabricated and is available) would then have to be baked to remove the residual water in the refractory. Nonradioactive testing would then be required to ensure that the system functions as intended. This approach would eliminate the concern of exceeding the NTS limits for TRU and RCRA metals due to contamination.

\section{CONCLUSIONS}

In order to meet the NTS WAC for the CST vitrification demonstration, the existing melter within the Shielded Cells must first be flushed with non-radioactive, non-hazardous glass. Due to the high levels of TRU and RCRA metals in the existing glass, $\sim 10$ melter volumes of material need to be processed to ensure acceptable TRU and RCRA metals levels. A strategy must be developed and implemented to provide the best opportunity for realizing this goal. This may include some periods or equilibration beiween pours, lowering and/or increasing the molten glass level in the melt pot, and use of different non-radioactive glasses. Sampling and analysis of the glass from the pour stream will be required such that the efficiency of the flushing process can be monitored. It is anticipated that the analytical feedback will provide direction to the actual approach. 
At a melter throughput of $\sim 1$ pound of glass per hour at $50 \%$ attainment ( 24 hours per day), flushing would take $\sim 20$ days. Additional steps in the protocol, such as equilibration, sample analysis, etc., will increase the overall time for melter flushing. Once an acceptable level of radionuclides and RCRA metals is obtained, there is still the risk, as discussed above, that pieces of glass or dried slurry could release, mix with the glass, and cause the waste glass to exceed NTS limits.

If a reduced scope of this task is realized, then the vitrified CST will be disposed of at SRS. In this case, the degree of flushing required will depend upon (1) SRS requirements for waste disposal and (2) task objectives for obtaining required data on the vitrified CST (i.e., the degree of contamination of the glass samples that can be tolerated). A separate report detailing these items will be issued.

\section{REFERENCES}

1. J. F. Walker, LMER Pretreatment, TTP OR1-6-WT-41, 1996.

2. W. F. Kinard, N. E. Bibler, C. J.Coleman, and R. A. Dewberry, Radiochemical Analyses for the Defense Waste Processing Facility Startup at the Savannah River Site, Journal of Radioanalytical and Nuclear Chemistry, Vol. 219, No.2, 1997.

\section{DISTRIBUTION}

M. K. Andrews, 773-A

N. E. Bibler, 773-A

D. A. Crowley, 773-43A

E. F. Duhn, 773-A

D. M. Ferrara, 773-43A

B. C. Ha, 773-43A

J. R. Harbour, 773-43A

E. W. Holtzscheiter, 773-A

L. F. Landon, 704-1T

M. J. Plodinec, 773-A

C. T. Randall, 704-T 


\section{Attachment 2.}

M. K. Andrews, "Glass Formulation Development and Testing for the Vitrification of Cesium-Loaded Crystalline Silicotitanate (CST)," conference proceedings from the Air and Waste Management Association Annual Meeting (1997).

$$
\begin{aligned}
& \text { conference } \\
& \text { WSRC-MS--97-00041 } \\
& \text { cycled } \\
& \text { separately. }
\end{aligned}
$$




\section{Attachment 3.}

M. K. Andrews, T. L. Fellinger, D. M. Ferrara, J. R. Harbour, and D. T. Herman, "Vitrification of Cesium-Loaded Crystalline Silicotitanate (CST) in the Shielded Cells Melter (U),"WSRC-TR-97-00314 (1996). 


\author{
Westinghouse Savannah River Company \\ Savannah River Technology Center
}

WSRC-TR-97-00314 .

September 30, 1997

\title{
VITRIFICATION OF CESIUM-LOADED CRYSTALLINE SILICOTITANATE (CST) IN THE SHIELDED CELLS MELTER (U)
}

\author{
M. K. Andrews, T. L. Fellinger, D. M. Ferrara, J. R. Harbour and D. T. Herman \\ Westinghouse Savannah River Company
}

\section{Introduction and Summary}

Through the Tanks Focus Area, the Savannah River Technology Center (SRTC) and the Oak Ridge National Laboratory (ORNL) participated in a joint project in which supernate waste from the Melton Valley Storage Tanks at Oak Ridge was treated by passage through a crystalline silicotitanate (CST) ion exchange column. ${ }^{1}$ CST was designed to sorb Cs-137, Sr-90 and several other radionuclides from highly alkaline solutions containing large quantities of sodium. ${ }^{2}$ After demonstrating the effectiveness of CST as an ion exchange medium, ORNL shipped some of the loaded sorbent to SRTC where it was mixed with glass formers and processed in a joule-heated melter within the SRTC Shielded Cells.

The remotely operated process included the preparation of the melter feed, vitrification in an $1150^{\circ} \mathrm{C}$ melter and analysis of the glass product both for its composition and its durability. The campaign processed approximately $20 \mathrm{~kg}$ of Cs-loaded CST in 80 hours of operation of the Shielded Cells melter. The glass produced contained between 50 and $55 \mathrm{wt} \%$ loaded CST. This report details the results of the melter run, along with the preparations that were required to complete the campaign.

\section{CST Characterization}

A small sample of loaded CST from ORNL was removed from the top of the drum and dissolved for analysis using a peroxide/hydrofluoric acid/nitric acid dissolution. The resulting samples were analyzed using Inductively Coupled Plasma-Emission Spectroscopy (ICP-ES), Atomic Absorption (AA), and Gamma Spectroscopy. The manufacturer of the CST has requested that the elemental composition not be released, and therefore, only the radionuclide composition is reported in Table 1 . It should be noted that ORNL also performed some analyses on the CST and determined that it was neither characteristically hazardous nor TRU (less than $100 \mathrm{nCi} / \mathrm{g}$ alpha). The radionuclide composition that ORNL determined to have loaded on the CST is also included in Table 1. 
Table 1 - Major Radionuclide Composition of Loaded CST (SRTC Analyzed and ORNL Calculated)

\begin{tabular}{|c|c|c|}
\hline Element & SRTC (Ci) & ORNL (Ci) \\
\hline \hline Cs-137 & 19 & 24 \\
\hline Cs-134 & 0.2 & 0.3 \\
\hline Sr-90 & 0.1 & 0.2 \\
\hline
\end{tabular}

The elemental composition of the loaded CST was compared to the unloaded CST composition. The main difference was in the concentrations of sodium and potassium. The loaded CST was pretreated at ORNL with a sodium hydroxide solution to condition the CST and to remove fine particulates and therefore, contained more sodium and potassium. The loaded CST also contained cesium and strontium. The development of the final glass formulation for the melter run addressed these compositional differences.

\section{Glass Formulation Development}

Prior to the vitrification in the SRTC Shielded Cells, a glass formulation had to be developed to incorporate sufficient CST sorbent without significant crystallization. A report detailing the development of a glass formulation using unloaded CST has been written. ${ }^{3}$ Since the composition of the loaded CST was slightly different from the unloaded composition, the original formulation, along with four additional formulations were tested using pretreated (but unloaded) CST, at waste loadings of $50 \mathrm{wt} \%$.

The electrical conductivities for the five formulations were calculated to ensure that they would be compatible with the joule-heated melter. Typically, electrical conductivities between 0.36 and 1.1 Siemans $/ \mathrm{cm}$ at $1150^{\circ} \mathrm{C}$ are considered reasonable. Two compositions were at the higher end, but were within the acceptable range, one was above the high end and two were only slightly above the 1.1 Siemans $/ \mathrm{cm}$. The calculations were only estimates since the exact contributions of all of the elements present in the glass were not known. Therefore, it was decided to continue testing of all five formulations.

Two samples of each of the five formulations were melted at $1150^{\circ} \mathrm{C}$. The first sample was poured, and the second was subjected to a slower cooling rate, similar to that expected in the Shielded Cells melter. Two of the five samples, including the original formulation; were too fluid when poured. Two of the remaining samples formed crystals when slowly cooled. The fifth composition was within the required viscosity range and did not form crystals upon slow cooling. However, this composition had a calculated electrical conductivity slightly above the acceptable range. Since changing the composition to improve the conductivity could adversely affect the viscosity or the crystallization, it was decided to proceed with this formulation without reducing the waste loading. 
During the development of the glass formulation, a waste loading of $50 \mathrm{wt} \%$ dried CST was used. To ensure that the formulation was robust enough to handle variations in waste loadings, the selected composition was tested at lower and higher waste loadings. Based on the results of these experiments, it was determined that the formulation could easily incorporate CST loadings between 40 and $55 \mathrm{wt} \%$ dry CST. Since the CST received from ORNL contained 8 to $15 \mathrm{wt} \%$ water, the waste loading targeted was equivalent to a final CST loading in the glass between 50 and $55 \mathrm{wt} \%$, depending on the water content of the CST. The appropriate reagent-grade chemicals were then combined to produce the glass-forming chemicals for the melter campaign.

\section{Feed Delivery System}

Once the glass-forming chemicals were combined with the CST, a feed system with the ability to remotely provide feed for the entire melter campaign was required. The feed system needed to accommodate the possibility that several transfers of CST from the drum would be necessary. It was also necessary for the feed system to be able to mix the CST and chemicals to such a degree as to obtain a reasonably homogeneous feed for the melter. The feed was to be delivered to the melter at approximately $25 \mathrm{cc} /$ minute, and the system had to be able to withstand the high radiation fields in the Shielded Cells environment.

Most efforts focused on the delivery of the CST resin as a slurry because SRTC has experience pumping slurries to melters. Early tests with unloaded CST and water indicated that there was essentially no suspension of the solids in the liquid. The extremely low flow at which the feed was to be delivered to the melter did not allow for a velocity high enough to suspend the solids. Agitation in the feed drum was also not sufficient to suspend the solids. A recirculation loop using a diaphragm pump was added. The first system had a smaller line for feeding the melter off of the recirculation loop and used a needle valve for controlling the feed rate. Serious. plugging was encountered in the lines and especially in the needle valve.

It was then decided that in order to increase the suspension of the CST solids, the material needed to be ground. The diaphragm pump and the agitator in the feed drum were allowed to grind the material through recirculation. A 90-degree elbow was added to the system to increase the turbulence in the recirculation line. The erosion of this elbow would not be of concern due to the relatively short duration of the demonstration. A private company would have the option of adding an emulsifier to the recirculation line to allow more efficient and consistent grinding of the particles. The implementation of a recirculation loop in conjunction with agitation resulted in the grinding of the CST particles to a small enough size to maintain sufficient suspension and allow the delivery of the material in a reasonably homogeneous slurry. The needle valve in the melter feed line was replaced with a ball valve. A Masterflex pump after the ball valve was used to control the feed rate of the CST material to the melter. A schematic of the slurry feed system is shown in Figure 1. Several connections were added to allow for water flushing of the lines to prevent pluggage. 


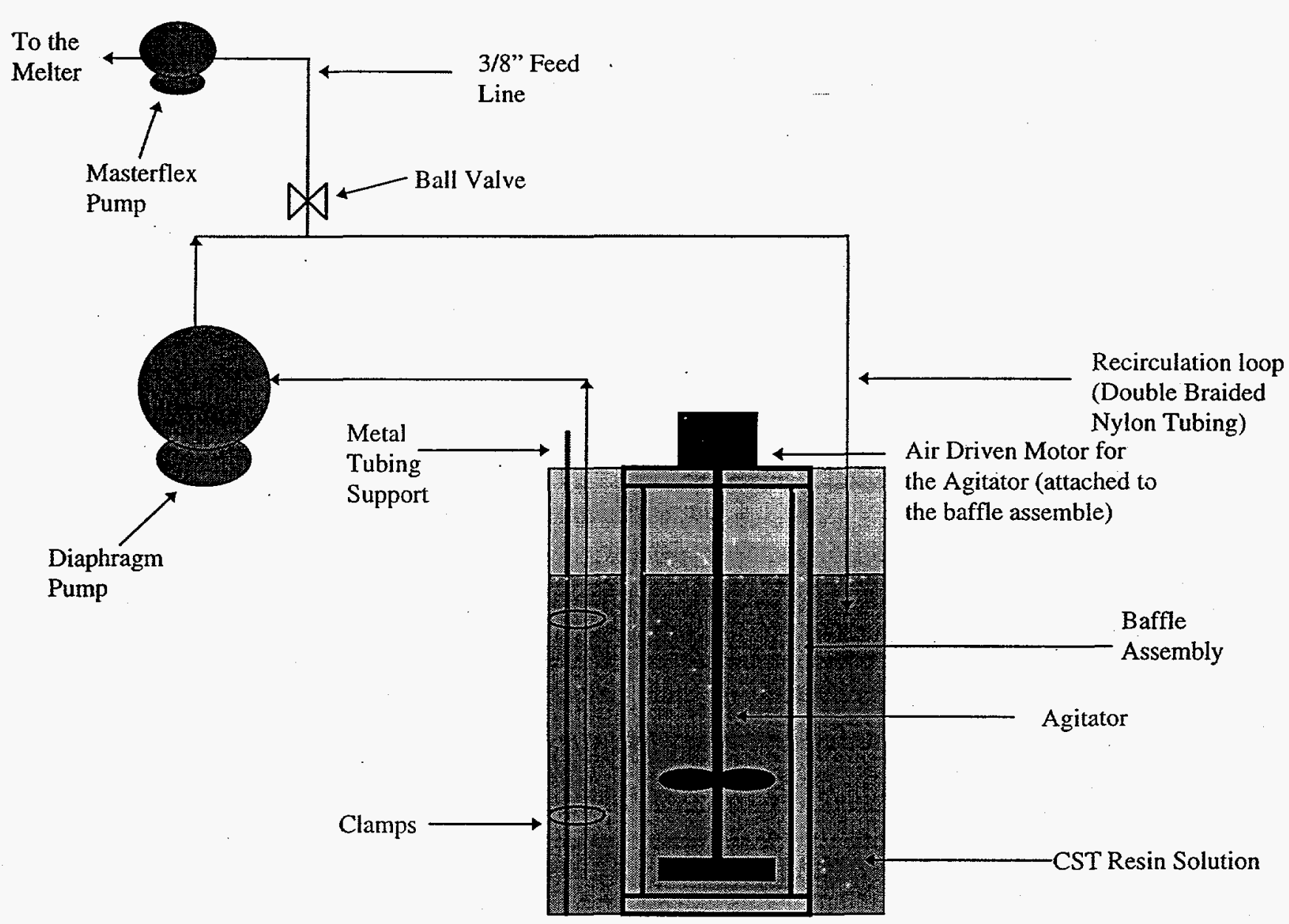

Figure 1 - Schematic of the Melter Feed Tank System in the Shielded Cells

The addition of the glass formers to the CST changed the rheology of the slurry from a thin water-like fluid to a fluid with the consistency of house paint. The particles tended to stay suspended for a longer period of time. Full-scale mock-up testing of the feed indicated that the use of a diaphragm pump and agitator caused sufficient grinding of the material to allow the material to remain suspended. The pumping/mixing setup successfully fed a CST and glass formers solution to the melter at a feed rate of approximately $27 \mathrm{cc} / \mathrm{min}$. Several full pump-down tests were successfully conducted with the CST as well as the CST plus glass former slurries.

Since the slurry feeding system required the addition of water to the CST, additional waste would be created from the condensate generated during vitrification. Therefore, a dry feed system was also tested. A sample of the radioactive CST was combined with the appropriate amount of glass-forming chemicals and was successfully vitrified in a platinum crucible in the Shielded Cells, indicating that dry CST and chemicals could be sufficiently mixed remotely. In addition, nonradioactive frit was added to the Shielded Cells melter as a dry mixture. No problems were encountered during the dry additions. 
Based on the results of this testing, the dry feed system was selected for use during the radioactive melter campaign. However, since both feed systems have been developed and tested, a private vendor would have the option of slurry feeding or dry feeding.

\section{Vitrification Process}

The research melter is a joule-heated melter with two pairs of Inconel® electrodes providing the power to maintain a melt pool temperature of $1150^{\circ} \mathrm{C}$. The cylindrical melt chamber is eight inches in diameter and six inches deep and holds approximately ten kilograms of glass. Two additional heaters are located in the melter above the melt pool to provide supplemental heat which increases the melt rates by vaporizing any water from the feed.

Glass pouring is initiated by tilting the entire melter. The glass flows from the melt pool through a riser cut in the refractory, and out a heated pour spout into 0.5 liter stainless steel beakers. During the CST campaign, the melter ran continuously for 85 hours producing nearly $30 \mathrm{~kg}$ of glass, or the equivalent of three melter turnovers. Prior to the initiation of CST feeding, the melter contained approximately $10 \mathrm{~kg}$ of nonradioactive glass. As feeding of the CST material progressed, the conductivity of the melt pool increased as expected since the CST glass was calculated to be more conductive than the nonradioactive glass. After more than $20 \mathrm{~kg}$ of glass had been produced, the melt temperature was reduced from $1150^{\circ} \mathrm{C}$ to $1125^{\circ} \mathrm{C}$ to lower the current density across the electrodes. With a different melter, this may not have been necessary, but since the Shielded Cells melter has been operating for seven years, it was decided to be conservative. No other melter differences were encountered.

\section{Glass Characterization}

Since the melter contained nonradioactive glass prior to the start of the CST run, samples of glass were taken from the last can poured during the campaign. The last can was chosen because it would have a composition most representative of the feed. Glass from the CST campaign was taken for the purpose of determining its composition and its durability by leaching it according to the Product Consistency Test (PCT) protocol. ${ }^{4}$

The composition of the glass is being measured by dissolving samples of the glass in duplicate and analyzing the resulting solutions by ICP-ES, AA and Gamma Spectroscopy. Appropriate standards are being analyzed along with the CST glass samples to check the accuracy of the analyses.

The PCT is currently being used to determine the durability of the glass. The PCT is a crushed glass leach test that measures the releases of boron, lithium, sodium, and silicon from the glass in $90^{\circ} \mathrm{C}$ ASTM Type 1 water over a period of seven days. The average concentrations are normalized to the chemical composition of the glass. The normalized results for CST glass will be provided in a revision to this report. The HLW acceptance criteria, which states that the glass produced must be more durable than the Environmental Assessment (EA) glass, will be used as the basis for determining acceptability of the CST glass. 


\section{Acknowledgments}

We would like to acknowledge the contributions of Phyllis Workman, Kathy Marshall, Debbie Marsh, Sherry Vissage, Bao Ha, the Shielded Cells Operations, and the Analytical Development Section. This project would not have been successful without their assistance.

\section{References}

the 1. Joe Walker, LMER Pretreatment, OR1-6-WT-41, (1996).

2e. 2. R. Braun et al, "Crystalline Silicotitanate - Novel Commercial Cesium Ion Exchangers", Spectrum '96, Proceedings - International Topical Meeting on Nuclear and Hazardous Waste Management, (1996).

3. M. K. Andrews, "Glass Formulation Development and Testing for the Vitrification of Cesium-Loaded Crystalline Silicotitanate (CST)", 97-MP23.05, Proceedings of the Air \& Waste Management Association's 90 ${ }^{\text {th }}$ Annual Meeting and Exhibition, (1997).

4. ASTM Procedure, C-1286-94, "Determining Chemical Durability of Nuclear Waste Glasses: The Product Consistency Test (PCT)".

t... 5. U. S. Department of Energy, "Environmental Assessment Waste Form Selection for SRP High-Level Waste", USDOE Report DOE-EA-0179, (1982). 
Attachment 4.

K. M. Marshall, T. L. Fellinger, and J. R. Harbour, "Final Flush of the Shielded Cells Melter (U)," WSRC-TR-97-00316 (1997). 
September 29, 1997

\title{
FINAL FLUSH OF THE SHIELDED CELLS MELTER (U)
}

\author{
Kathryn M. Marshall, Terri L. Fellinger, John R. Harbour
}

Westinghouse Savannah River Company

\section{INTRODUCTION}

A flush of the Savannah River Technology Center (SRTC) Shielded Cells melter was performed after the completion of a campaign to vitrify loaded crystalline silicotitanate (CST) ion exchange medium. The purpose of the flush was to lower levels of radioisotopes accumulated during the campaign and to lower the level of titanium dioxide present in the glass. This in turn would ready the melter for future campaigns involving the Defense Waste Processing Facility (DWPF).

The CST campaign began in August and was completed in September of 1997. The material that was vitrified had been used to sorb cesium and strontium from the Melton Valley Storage Tanks at the Oak Ridge National Laboratory (ORNL). It was loaded

primarily with Cesium-137, and with smaller amounts of strontium. ${ }^{1}$ At the beginning of the flush, the melter contained approximately ten kilograms of fifty-weight percent CSTloaded borosilicate glass. With this amount of glass, there was approximately 3.29 Curies in the melter ${ }^{2}$. In addition, the glass contained greater than one-weight percent titanium dioxide, a component of the CST. Constraints on the composition of DWPF glass limit titanium dioxide content to below one-weight percent. Approximately forty kilograms of the DWPF startup frit, black Frit 565, were used to flush this material out of the melter.

\section{NONRADIOACTIVE DWPF FEED}

Frit 565 is a borosilicate frit intended for startup activities in the DWPF. The frit formulation is shown in Table 1. The frit was first mixed with sea sand in the ratio of 9:1 and then fed to the melter in batches. Sea sand was added to the frit to increase the silica content, which served to decrease the liquidus temperature of the frit, and reduce crystal formation. Approximately forty kilograms of the frit and sand mixture were added to the melter for the flush. 
Table 1. Black Frit 565 Formulation $^{3}$

\begin{tabular}{ll} 
Component & Weight \% \\
\hline $\mathrm{SiO}_{2}$ & 49 \\
$\mathrm{~B}_{2} \mathrm{O}_{3}$ & 8.8 \\
$\mathrm{Li}_{2} \mathrm{O}$ & 3.5 \\
$\mathrm{Na}_{2} \mathrm{O}$ & 11.5 \\
$\mathrm{MgO}$ & 0.7 \\
$\mathrm{CaO}$ & 1.2 \\
$\mathrm{TiO}_{2}$ & 1 \\
$\mathrm{Fe}_{2} \mathrm{O}_{3}$ & 13.5 \\
$\mathrm{Al}_{2} \mathrm{O}_{3}$ & 4.7 \\
$\mathrm{MnO}_{2}$ & 2.3 \\
$\mathrm{NiO}$ & 1.1 \\
$\mathrm{~K}_{2} \mathrm{O}$ & 2.6 \\
$\mathrm{Cr}_{2} \mathrm{O}_{3}$ & 0.1 \\
\hline & 100
\end{tabular}

\section{MELTER FLUSH OPERATION}

At the end of the CST vitrification campaign, the SRTC Shielded Cells melter contained approximately ten kilograms of fifty-weight percent CST-loaded glass, at a level of approximately 3.29 Curies. $^{2}$ The glass also contained greater than the acceptable amount of titanium dioxide for DWPF composition control. In order to reduce the level of cesium and titanium, a flush was completed using DWPF black Frit 565.

The frit was added in batches via a funnel placed in the feed tube, located on top of the melter. Feedings took place in intervals of about twenty minutes. A feed batch was approximately 113 or $225 \mathrm{ml}$, depending on the rate the glass was pouring from the melter. During feeding, molten glass was poured into stainless steel beakers that each held approximately one kilogram of glass. By roughly matching the glass pour rate with the frit feed rate, the glass level in the melter remained essentially constant throughout flushing.

Total time of the feeding and pouring operation was approximately sixty-six hours. The total frit fed over the sixty-six hours was forty kilograms, and the total glass poured was thirty-nine kilograms. The glass was poured into thirty-six cans. See Attachment 1 for details of the flush. 


\section{RESULTS}

The Shielded Cells melter was flushed with DWPF black Frit 565 in order to reduce the levels of titanium and cesium in the vessel, as well as to prepare the melter for future campaigns. The thirty-nine kilograms of glass poured during the flush represent 3.9 turnovers of the melter volume. The concentration of cesium after 3.9 melter volumes is expected to be reduced to 0.0215 of its original concentration (See Attachment 2 for graphical analysis). With the initial loading of cesium contributing approximately 3.29 Curies $^{2}$ to the melter, the final concentration of cesium is expected to be reduced to 0.071 Curies. This corresponds to 0.0071 Curies per kilogram of glass in the melter. By the same calculation, the original concentration of titanium dioxide in the melter should be reduced to well below one-weight percent. ${ }^{2}$

\section{REFERENCES}

1. Joe Walker, LMER Pretreatment, OR1-6-WT-41, 1996.

2. M. K. Andrews, et al., "Vitrification of Cesium-Loaded Crystalline Silicotitanate in the Shielded Cells Melter", WSRC-TR-97-00314, September 1997.

3. C. M. Jantzen, "Glass Composition and Frit Formulations Developed for DWPF", DPST-88-952, November 1988. 
ATTACHMENT 1: MELTER FLUSH

(Ref: WSRC-NB-90-319)

\begin{tabular}{|c|c|c|c|c|c|c|}
\hline Date & $\begin{array}{l}\text { Time } \\
\text { Put in }\end{array}$ & Can & $\begin{array}{l}\text { Cumulative } \\
\text { Glass Poured (kg) }\end{array}$ & $\begin{array}{l}\text { Cumulative CST } \\
\text { Batch Fed (g) }\end{array}$ & $\begin{array}{l}\text { Cumulative } 565 \\
\text { Frit Fed }(g)\end{array}$ & NOTES \\
\hline & $15: 45$ & C31 & 1.1749 & & 2500.001 & \\
\hline & $16: 45$ & & & & & Operation stopped; 1 bag frif fed \\
\hline $9 / 4 / 97$ & 14:00 & & & & & Operation resumed \\
\hline & $16: 20$ & C32 & 2.1749 & & 3146.55 & \\
\hline & 17:20 & C33 & 3.2174 & & 4116.38 & Operation stopped \\
\hline $9 / 5 / 97$ & $9: 35$ & & & & & Operation resumed \\
\hline & $10: 35$ & C34 & 4.3764 & & 5086.21 & \\
\hline & 11:55 & C35 & 5.5369 & & 6056.03 & \\
\hline & $12: 45$ & C36 & 6.6633 & & 7672.41 & Operation stopped; C36 empty \\
\hline $9 / 8 / 97$ & $8: 40$ & & & & & Operation resumed \\
\hline & 10:00 & C37 & 7.7534 & & 8318.97 & \\
\hline & 11:45 & C38 & 8.7936 & & 9450.43 & \\
\hline & 13:50 & C39 & 9.8856 & & 10420.26 & \\
\hline & 15:25 & C40 & 10.9347 & & 11390.09 & \\
\hline & 17:10 & C41 & 11.6920 & & 12036.64 & \\
\hline & 18:00 & C42. & T2.7649 & & 13329.74 & \\
\hline & $18: 40$ & & & & & Operation stopped \\
\hline 9/9/97 & $6: 10$ & & & & & Operation resumed \\
\hline & $8: 00$ & $\mathrm{C} 43$ & 13.9399 & & 14461.21 & \\
\hline & $9: 45$ & $\mathrm{C} 44$ & 15.0929 & & T5592.67 & \\
\hline & T1:20 & C45 & 16.0189 & & 16724.14 & \\
\hline & 13:05 & C46 & 17.0908 & & 17693.97 & \\
\hline & $14: 40$ & C47 & 18.1285 & & 18825.43 & \\
\hline & $16: 40$ & C48 & 19.2051 & & 19633.62 & \\
\hline & $18: 00$ & $\mathrm{C} 49$ & 20.2387 & & 21250.00 & \\
\hline & $18: 40$ & & & & & Operation stopped \\
\hline $9 / 10 / 97$ & $6: 10$ & & & & & Operation resumed \\
\hline & $8: 20$ & $\mathrm{c50}$ & 21.2382 & & 22381.47 & \\
\hline & $10: 15$ & C51 & 22.2480 & & 23189.66 & \\
\hline & $11: 55$ & $C 52$ & 23.4977 & & 24644.40 & \\
\hline & 13:50 & $\mathrm{C53}$ & 24.5302 & & 25775.86 & \\
\hline & 15:30 & C54 & 25.6887 & & 26422.41 & \\
\hline & $16: 35$ & $c 55$ & 26.6916 & & 27715.52 & \\
\hline & 17:50 & & & & & Operation stopped \\
\hline 9/21/97 & $6: 10$ & & & & & Operation resumed \\
\hline & $7: 35$ & $C 56$ & 27.7374 & & 29008.62 & \\
\hline & $9: 35$ & C57 & 28.7880 & & 30140.09 & \\
\hline & 11:30 & C58 & 29.8434 & & 30786.64 & \\
\hline & 12:55 & C59 & 30.9015 & & 31756.47 & \\
\hline & 75:10 & 660 & 31.9946 & & 32726.29 & \\
\hline & $77: 10$ & C6T & 33.1141 & & 34019.40 & \\
\hline & 18:00 & & & & & Operation stopped \\
\hline $9 / 15 / 97$ & $6: 05$ & & & & & Operation resumed \\
\hline & 8:45 & C62 & 34.1378 & & 35312.50 & \\
\hline & 10:55 & C63 & 35.3884 & & 36605.60 & \\
\hline & $12: 55$ & C64 & 36.4215 & & 38221.98 & \\
\hline & 75:00 & C65 & 37.6514 & & 39030.17 & \\
\hline & $16: 50$ & C66 & 38.7377 & & 40000.00 & \\
\hline & 18:10 & 1730 & & & & Operation stopped; Can \\
\hline
\end{tabular}


ATTACHMENT 2: Melter Turnover Graph

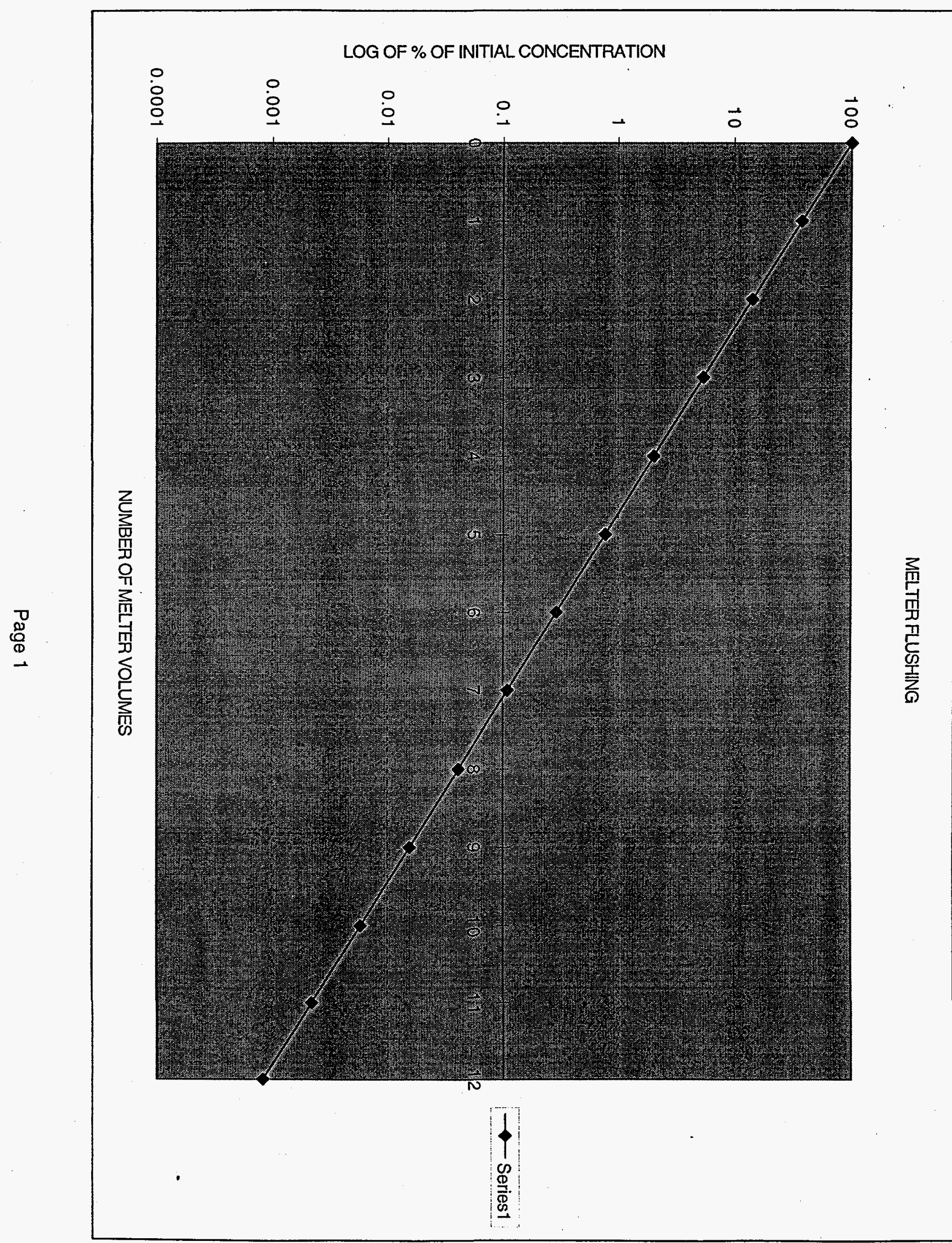




\section{Attachment 5 .}

J. R. Harbour and M. K. Andrews, "Compliance with the Nevada Test Site's Waste Acceptance Criteria for Vitrified Cesium-Loaded Crystalline Silicotitanate (CST)," conference proceedings for the Air and Waste Management Association Annual Meeting, (1997).

$$
\begin{aligned}
& \text { conference } \\
& \text { paper } \\
& \text { WSRC-MS-97-00050 } \\
& \text { cycled } \\
& \text { separately. }
\end{aligned}
$$




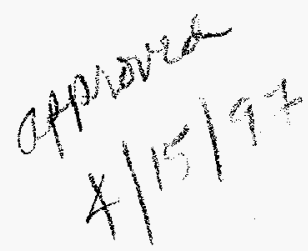

\section{Attachment 6.}

M. K. Andrews and J. R. Harbour, "Glass Formulation Requirements for DWPF Coupled Operations Using Crystalline Silicotitanates (U)," WSRC-TR-97-0004 (1997). 
WSRC-TR-97-0004

Revision 0

Keywords: TFA, CST, Cesium, DWPF, ORNL, Coupled

January 9, 1997

\title{
GLASS FORMULATION REQUIREMENTS FOR DWPF COUPLED OPERATIONS USING CRYSTALLINE SILICOTITANATES (U)
}

\author{
Mary K. Andrews and John R. Harbour \\ - Westinghouse Savannah River Company \\ Savannah River Technology Center \\ Aiken, South Carolina
}

\section{INTRODUCTION}

The design basis DWPF flowsheet couples the vitrification of two waste streams: (1) a washed sludge and (2) a hydrolyzed sodium tetraphenylborate precipitate product, PHA. The PHA contains cesium-137 which had been preciptitated from the tank supernate with sodium tetraphenylborate. Smaller amounts of strontium and plutonium adsorbed on sodium titanate are also present with the PHA feed. Currently, DWPF is running a sludge-only flowsheet while working towards solutions to the problems encountered with in Tank Precipitation (ITP). The sludge loading for the sludge-only flowsheet and for the anticipated coupled operations is $28 \mathrm{wt} \%$ on an oxide basis ${ }^{1}$. For the coupled operation, it is essential to balance the treatment of the two waste streams such that no supernate remains after immobilization of all the sludge. (Under the current plans, this will involve filling over 5,000 canisters in $\sim 20$ years $\left.{ }^{1}\right)$.

An alternative to ITP and sodium titanate is the removal of Cs-137, Sr-90, and plutonium from the tank supernate by ion exchange using crystalline silicotitanate (CST) ${ }^{2,3}$. This material has been shown to effectively sorb these elements from the supernate ${ }^{2}$. It is also known that CST sorbs plutonium ${ }^{2}$. The loaded CST could then be immobilized with the sludge during vitrification. It has recently been demonstrated that CST loadings approaching $70 \mathrm{wt} \%$ for a . CST-only glass can be achieved using a borosilicate glass formulation which can be processed by the DWPF melter $r^{4}$. Initial efforts on coupled waste streams with simulated DWPF sludge show promise that a borosilicate glass formulation can incorporate both sludge and CST. This paper presents the bases for research efforts to develop a glass formulation which will incorporate sludge and CST at loadings appropriate for DWPF operation. 


\section{DWPF BACKGROUND}

During the anticipated coupled operation at DWPF, glass will be produced that contains $28 w t \%$ sludge oxides and $8 w t \%$ oxides from precipitate processing. The remaining $64 \mathrm{wt} \%$ will be the borosilicate frit. The $28 \mathrm{wt} \%$ sludge will be the minimum acceptable loading for the CST-coupled formulation work.

The design basis glass for the DWPF coupled operation contains 4.33E+04 Curies of Cs-137 per canister (based on 3,700 pounds of glass/canister). Since there are 1.153E-02 grams of $\mathrm{Cs}-137 / \mathrm{Ci}$, each DWPF canister will contain 499 grams of Cs-137. For a canister containing $1678 \mathrm{~kg}(3,700 \mathrm{lbs})$, this is equivalent to a 0.03 wt\% loading of Cs-137 in the glass. This 0.03 wt\% Cs-137 loading must be achieved or exceeded in order for CST to be a viable alternative for the DWPF. Since the Cs-137 accounts for approximately 38 atom\% of the cesium present ${ }^{3}$ in the supernate, the total cesium concentration in the glass must be at least $0.08 \mathrm{wt} \%$.

\section{CST CAPACITY}

Capacity measurements for Cs-137 loading on CST have been performed using a DWPF simulated salt solution. $\mathrm{McCabe}^{3}$ has demonstrated a range of 1.2 to $4.6 \mathrm{wt} \%$ cesium sorption on powdered CST depending upon the cesium concentration in solution (for fixed sodium and potassium levels). For the DWPF supernate, which contains 38 atom\% Cs-137, these values translate to 0.5 to $1.8 \mathrm{wt} \% \mathrm{Cs}-137$ sorption on the CST. The measured capacities of CST for $\mathrm{Cs}$ at various concentrations of $\mathrm{Cs}$ in solution are provided in Table 1. These data were taken directly from the report by $\mathrm{McCabe}^{3}$.

TABLE 1

CESIUM CAPACITY MEASUREMENTS ON CST FROM MCCABE (@5.6 M NaOH AND $0.015 \mathrm{M} \mathrm{KNO}_{3}$ )

\begin{tabular}{|c|c|lc|}
\hline Initial [Cs] & Kd & \multicolumn{2}{|c|}{ Cs/g CST } \\
\hline $\mathrm{mg} / \mathrm{L}$ & $\mathrm{mL} / \mathrm{g}$ & $\mathrm{mg}$ & $(\mathrm{wt} \%)$ \\
\hline 28.25 & 1948 & 11.59 & $(1.2 \%)$ \\
\hline 48.67 & 1971 & 19.73 & $(2.0 \%)$ \\
\hline 63.17 & 1980 & 24.7 & $(2.5 \%)$ \\
\hline 74.41 & 1796 & 28.76 & $(2.9 \%)$ \\
\hline 117.2 & 1094 & 40.31 & $(4.0 \%)$ \\
\hline 139 & 988 & 45.61 & $(4.6 \%)$ \\
\hline
\end{tabular}

\section{CST GLASS LOADING REQUIREMENTS}

A 0.03 wt\% loading of Cs-137 in the final glass waste form must be achieved for a balanced coupled operation. Table 2 provides the required Cs-137 loading on CST (for various loadings of CST in glass) that will meet the overall 0.03 $w t \%$ Cs-137. These results are plotted in Figure 1. (Figure 1 presents data up to $20 \mathrm{wt} \%$ CST in glass. Table 2 provides CST loadings in glass up to-40 wt\%.) 
At 5 wt $\%$ CST in glass, a loading of $0.6 w t \%$ Cs-137 must be achieved. However at 20 wt\% CST, the amount of Cs-137 sorbed must reach only 0.15 $w t \% \mathrm{Cs}-137$. This corresponds to $0.127 \mathrm{Ci} / \mathrm{g} \mathrm{CST}$. At $40 \mathrm{wt} \% \mathrm{CST}$, the amount of Cs-137 sorbed on CST must reach 0.07 wt\%. The path forward (see below) will use these data to provide some flexibility, if possible, for the use of CST as a replacement for ITP for the DWPF.

TABLE 2

CST GLASS LOADING REQUIRED AS A FUNCTION OF SORBED Cs-137 FOR $0.025 \mathrm{Ci} / \mathrm{g}$ GLASS

\begin{tabular}{|c|c|c|}
\hline GLASS & CST & CST \\
\hline CST Loading (wt\%) & Ci Cs137/g CST & Wt\% Cs-137 \\
\hline 1 & 2.547 & 2.94 \\
\hline 2 & 1.274 & 1.47 \\
\hline 3 & 0.849 & 0.98 \\
\hline 4 & 0.637 & 0.73 \\
\hline 5 & 0.509 & 0.59 \\
\hline 6 & 0.425 & 0.49 \\
\hline 7 & 0.364 & 0.42 \\
\hline 8 & 0.318 & 0.37 \\
\hline$\overline{9}$ & 0.283 & 0.33 \\
\hline 10 & 0.255 & 0.29 \\
\hline 11 & 0.232 & 0.27 \\
\hline 12 & 0.212 & 0.25 \\
\hline 13 & 0.196 & 0.23 \\
\hline 14 & 0.182 & 0.21 \\
\hline 15 & 0.17 & 0.2 \\
\hline 16 & 0.159 & 0.18 \\
\hline 17 & 0.15 & 0.17 \\
\hline 18 & 0.142 & 0.16 \\
\hline 19 & 0.134 & 0.15 \\
\hline 20 & 0.127 & 0.15 \\
\hline 25 & 0.102 & 0.12 \\
\hline 30 & 0.085 & 0.1 \\
\hline 35 & 0.073 & 0.08 \\
\hline 40 & 0.064 & 0.07 \\
\hline
\end{tabular}




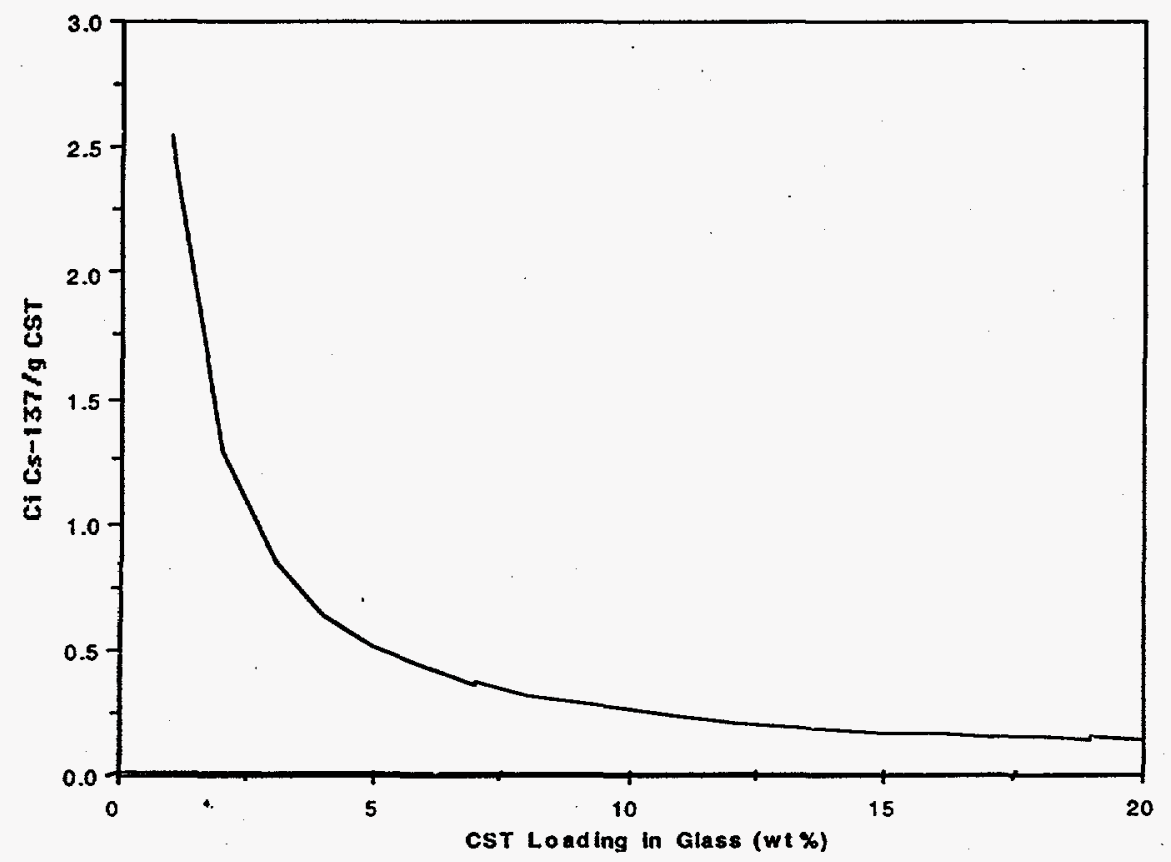

Figure 1. Curie Loading on CST a a function of CST Loading in the Glass

\section{DWPF TANK CHEMISTRY}

It is clear that the capacity of the CST for cesium will depend on the chemistry of the supernate. For example, an increase in potassium concentration at a constant sodium concentration will reduce the capacity of the CST for cesium. ${ }^{2}$ The DWPF tank supernate has significant, variable quantities of dissolved potassium $^{5}$ (see Table 3). Another variable affecting the amount of cesium sorbed is the concentration of Cs in the supernate at constant sodium and potassium levels (see Table 1). For DWPF, the Cs concentrations in the supernate are variable ${ }^{5,6}$ (Table 3). Therefore, any glass formulation developed for the coupled operation may have to accomodate the $\mathrm{Cs}-137, \mathrm{Na}$, and $\mathrm{K}$ variations. (Pretreatment of the supernate to optimize $\mathrm{Cs}, \mathrm{Na}$, or $\mathrm{K}$ concentrations may be possible.) Table 3 provides the sodium and potassium concentrations along with the Cs-137 levels for various tank supernates. These particular tank supernates are expected to be the first supernates which will be treated in ITP. Although saltcake will eventually be redissolved and treated, its effect is not included in this report.

An Operational Safety Requirement (OSR) ${ }^{7}$ limits the total sodium concentration in the supernate to $5 \mathrm{M}$ with the added requirement that hydroxyl ion concentration can not exceed half of the sodium level $(2.5 \mathrm{M})$. Thus, dilution of these tank supernates may be necessary. The concentrations of cesium at $5 \mathrm{M}$ sodium are therefore included in Table 3. 
TABLE 3

DWPF TANK CHEMISTRY

\begin{tabular}{|l|c|c|c|c|c|}
\hline & $\mathrm{Na}$ & $\mathrm{K}$ & TOTAL OH & $\mathrm{Cs}-137$ & $\mathrm{Cs}-137$ \\
\hline & (Molar) & (Molar) & (Molar) & $(\mathrm{mg} / \mathrm{L})$ & $@ 5 \mathrm{M} \mathrm{Na}$ \\
\hline TANK 25 & 13.6 & 0.17 & 10.6 & 13 & 4.8 \\
\hline TANK 26 & 16.7 & 0.18 & 15.2 & 16.7 & 5 \\
\hline TANK 27 & 12.1 & 0.14 & 9.9 & 11.4 & 4.7 \\
\hline TANK 28 & 13.2 & 0.13 & 8.5 & 13.5 & 5.1 \\
\hline TANK 29 & 14 & 0.086 & 6.5 & 33.8 & 12.1 \\
\hline TANK 30 & 9.1 & 0.039 & 3.9 & 24.9 & 13.7 \\
\hline TANK 32 & 5.3 & 0.019 & 2.1 & 11.4 & 10.8 \\
\hline TANK 38 & 19.1 & 0.083 & 9.6 & 11.4 & 3 \\
\hline TANK 43 & 14.4 & 0.085 & 10.4 & 7.8 & 2.7 \\
\hline
\end{tabular}

For the supernates listed in Table 3, the concentrations of Cs-137 range from 7.8 to $33.8 \mathrm{mg} / \mathrm{L}$. Dilution to $5 \mathrm{M} \mathrm{Na}^{+}$reduces the Cs levels and leads to a Cs137 range of 2.7 to $13.7 \mathrm{mg} / \mathrm{L}$. Assuming a linear extrapolation of McCabe's data to zero, one can calculate capacities for those cesium concentrations below that actually measured by McCabe. From the data in Table 2, one can then obtain the amount of CST which must be incorporated into the glass to achieve the required $0.03 \mathrm{wt} \% \mathrm{Cs}-137$. These results (some of which were taken from within McCabe's data range and some from extrapolation) are summarized in Tables 4 and 5.

TABLE 4

RANGE OF Cs-137 AND TOTAL Cs CONCENTRATIONS IN DWPF TANK SUPERNATES

\begin{tabular}{|l|c|c|}
\hline & CONCENTRATED RANGE & DILUTED RANGE \\
\hline $\mathrm{Cs}-137(\mathrm{mg} / \mathrm{L})$ & $7.8-33.8$ & $2.7-13.7$ \\
\hline Total Cs $(\mathrm{mg} / \mathrm{L})$ & $20.53-88.95$ & $7.11-36.05$ \\
\hline
\end{tabular}

TABLE 5

RANGE OF Cs-137 AND TOTAL CS SORBED ON CST AND CORRESPONDING CST LOADINGS IN GLASS

\begin{tabular}{|c|c|c|}
\hline & CONCENTRATED RANGE & DILUTED RANGE \\
\hline Cs/CST (wt\%) & $0.86-3.51$ & $0.3-1.5$ \\
\hline Cs-137/CST (wt\%) & $0.33-1.41$ & $0.12-0.57$ \\
\hline CST/Glass (wt\%) & $9-2$ & $27-5$ \\
\hline
\end{tabular}




\section{ORNL DEMONSTRATION}

ORNL is in the middle of a demonstration ${ }^{8}$ in which supernate from the Melton Valley Storage Tanks (MVST) is being treated with CST. ORNL was only able to sorb Cs-137 at $0.007 \mathrm{Ci} / \mathrm{g}$ CST. This is much less sorption than measured by McCabe with the DWPF surrogate supernate.

The reason for this low sorption appears to be related to the very low amount of cesium in solution. The MVST supernate contains only $0.58 \mathrm{ppm}$ total cesium and $0.14 \mathrm{ppm}$ of Cs-137. This can be compared to McCabe's lowest value of $28.8 \mathrm{mg} / \mathrm{L}$ or $\sim 28.8 \mathrm{ppm}$ total cesium. The difference is $\sim 50$ times less Cs-137 in the MVST than in the DWPF supernate surrogate. The sodium concentration in the MVST supernate is 4.1 Molar $(95400 \mathrm{ppm})$ and is relatively close to that used by McCabe for the DWPF study. However, the potassium concentration in the MVST supernate is $14700 \mathrm{ppm}$ or 0.4 molar. This is almost an order of magnitude higher than the concentration of potassium in the DWPF supernate. Since potassium competes with cesium for sorption, the higher levels of potassium could also account for lower cesium sorption.

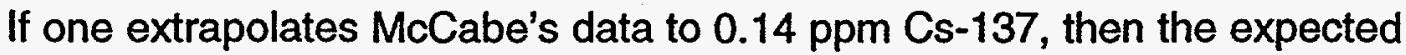
sorption of Cs on CST would be $0.006 \mathrm{wt} \%$. ORNL measured a value of 0.008 $w t \%$. This good agreement suggests that that the level of cesium in solution may be the major reason why ORNL has lower sorption of cesium.

\section{PATH FORWARD}

Two separate cases for glass formulation development are proposed ${ }^{9}$ in order to account for the uncertainties in the amount of Cs-137 which will load on CST and to provide limits for processing options.

Case 1. CONCENTRATED In the first case it is assumed that the amount of $\mathrm{Cs}$ sorbed is roughly equivalent to that demonstrated by McCabe using a surrogate DWPF supernate. A glass which incorporates $6 \%$ CST (with a loading of $\sim 0.5 \mathrm{wt} \% \mathrm{Cs}-137$ on the CST) would yield a glass with $0.03 \mathrm{wt} \%$ Cs-137, the value which is needed by DWPF to equalize the sludge and supernate. Therefore, a value near 5 wt $\%$ CST in the glass was chosen as a goal for Case 1. The sludge loading may be varied but will maintain at least a $28 \mathrm{wt} \%$ loading in the glass.

Case 2. DILUTED In this case, it is assumed that the amount of cesium sorbed on the CST may vary considerably. For tanks with supernates having low concentrations of cesium or high concentrations of competing ions, the amount of cesium sorbed on the CST may be less than reported by McCabe. Options for processing may also lead to a reduction in the amount of cesium sorbed by the CST. Therefore, an attempt will be made to maximize the amount of CST which can be incorporated in the glass along with the sludge. This will provide an upper limit for the amount of CST and consequently, a range for the amount of cesium which can be successfully loaded into a borosilicate waste glass containing DWPF sludge. 


\section{REFERENCES}

1. M. J. Plodinec and S. L. Marra, Projected Radionuclide Inventories and Radiogenic Properties of the DWPF Product (U), WSRC-IM-91116-3, Rev. 0, October, 1994.

2. R. Braun, T. J. Dangieri, D. J. Fennelly, J. D. Sherman, W. C. Schwerin, R. R. Willis et al, Crystalline Silicotitanates-Novel Commercial Cesium Ion Exchangers, Spectrum '96, Seattle, Washington, August 1996.

3. D. J. McCabe, Crystalline Silicotitanate Examination Results (U), WSRC-RP-94-1123, Rev. 0, September, 1994.

4. M. K. Andrews and J. R. Harbour, Effect of CST Ion Exchange Loading on the Volume of Glass Produced During the Vitrification Demonstration at SRTC (U), WSRC-TR-96-0372, Rev. 0, November, 1996.

5. R. S. Ondrejcin, Chemical Compositions of Supernates Stored in SRP High Level Waste Tanks, DP-1347, UC-70, Rev. 0, August, 1974.

6. D. D. Walker, C. J. Coleman, and R. A. Dewberry, Composition of Tnk Farm Supernate Samples (U), WSRC-RP-93-1009, Rev. 0, July, 1993.

7. Westinghouse Savannah River Company, Operational Safety Requirements, In-Tank Precipitation Process, Savannah River Site (U), WSRC-RP-90-1124, Rev. 2, June, 1993.

8. J. F. Walker Jr., LMER Pretreatment TPP, OR1-6-WT-41, October , 1996.

9. D. M. Ferrara, Immobilization of IX Resins (CST), WSRC Immobilization, TTP SR16WT31, Waste Tanks Immobilization, Task Number B, October, 1996. 


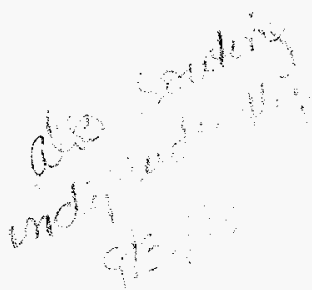

\section{Attachment 7.}

M. K. Andrews and P. J. Workman, "Glass Formulation Development and Testing for the Vitrification of DWPF HLW Sludge Coupled with Crystalline Silicotitante (CST) (U)," WSRC-TR-97-00312 (1997). 


\title{
GLASS FORMULATION DEVELOPMENT AND TESTING FOR THE VITRIFICATION OF DWPF HLW SLUDGE COUPLED WITH CRYSTALLINE SILICOTITANATE (CST) (U)
}

\author{
Mary K. Andrews and Phyllis J. Workman \\ Westinghouse Savannah River Company
}

\section{Introduction and Summary}

An alternative to the In Tank Precipitation (ITP) and sodium titanate processes at the Savannah River Site is the removal of cesium, strontium and plutonium from the tank supernate by ion exchange using crystalline silicotitanate (CST). This inorganic material has been shown to effectively and selectively sorb these elements from supernate. ${ }^{1}$ The loaded CST could then be immobilized with High-Level Waste (HLW) sludge during vitrification. Initial efforts on the development of a glass formulation for a coupled waste stream indicate that reasonable loadings of both sludge and CST can be achieved in glass.

As part of a Tanks Focus Area project, cesium that has been immobilized on a CST sorbent was combined with the Defense Waste Processing Facility (DWPF) HLW sludge and glass-forming chemicals and then vitrified in the Shielded Cells of the Savannah River Technology Center (SRTC). Prior to the demonstration, a glass formulation had to be developed to incorporate sufficient CST sorbent material along with DWPF HLW sludge.

A report has been issued that details the CST loading required in the glass. ${ }^{2}$ The CST loading in the glass is a function of the amount of cesium that can be sorbed by the CST. The crucible tests with simulated sludge and unloaded CST focused on glass formulations with approximately $5 \mathrm{wt} \% \mathrm{CST}$. Additional tests were also performed to try to maximize the CST loadings. In each case, the sludge loadings were around $28 \mathrm{wt} \%$ sludge oxides in the glass. The results of the glass formulation efforts are presented in this paper. 


\section{Experimental}

Scoping studies were performed using simulated sludge and unloaded CST. The composition of the sludge that was used during the scoping studies is provided in Table 1. These studies were performed to determine the type and amount of reagent grade chemicals that would be required to produce a durable glass with the appropriate liquidus and viscosity processing properties. The samples were thoroughly mixed and then vitrified in platinum crucibles. After approximately four hours at $1150^{\circ} \mathrm{C}$, the glasses were removed and either air cooled to room temperature, or slow cooled to room temperature following the DWPF canister centerline cooling regime. ${ }^{3}$ (The DWPF canister centerline cooling regime is an extremely slow cooling rate that is essentially equivalent to the slowest cooling rate experienced in a DWPF canister.) A few of the glass samples were removed from the furnace and poured to determine the viscosity range of the glass.

Table 1 - Major Elemental Composition of Simulated DWPF Sludge

\begin{tabular}{|c|c|}
\hline Element & Weight \% \\
\hline \hline $\mathrm{Al}$ & 6.85 \\
\hline $\mathrm{Ca}$ & 2.09 \\
\hline $\mathrm{Fe}$ & 27.63 \\
\hline $\mathrm{Mg}$ & 1.35 \\
\hline $\mathrm{Mn}$ & 2.92 \\
\hline $\mathrm{Na}$ & 6.90 \\
\hline $\mathrm{Si}$ & 0.94 \\
\hline
\end{tabular}

After the glasses had completely cooled, they were removed from the crucible and ground for analyses. The glasses were dissolved and characterized to determine the chemical composition. The crystalline content of the glass was measured by X-Ray Diffraction (XRD), and the durability of the glass was determined by the Product Consistency Test $(\mathrm{PCT}){ }^{4}$

After the initial scoping studies, a screening experiment was performed to increase the CST loading in the glass. The final composition of the glass formers was then determined by a small set of samples that was designed to optimize the waste loading. The final composition was then tested in the SRTC Shielded Cells using radioactive sludge from Tank 51 and radioactive CST. 


\section{Results and Discussion}

\section{Scoping Studies}

The scoping studies were performed to determine the type and amount of chemicals to combine with the nonradioactive sludge and unloaded CST to form a glass. Both the sludge and CST loadings were varied but the sludge loadings were kept close to the current loading of $28 \mathrm{wt} \%$ sludge oxides. Table 2 shows a sample of the waste loadings that were examined. Each of these samples represent a different glass composition.

Table 2 - Waste Loadings Tested during Scoping Studies

\begin{tabular}{|c|c|c|c|}
\hline Sample & $\begin{array}{c}\text { CST } \\
\text { wt\% }\end{array}$ & $\begin{array}{c}\text { Sludge } \\
\text { wt\% }\end{array}$ & $\begin{array}{c}\text { Glass Formers } \\
\text { wt\% }\end{array}$ \\
\hline \hline 1 & 5 & 25 & 70 \\
\hline 2 & 7 & 28 & 65 \\
\hline 3 & 8 & 28 & 64 \\
\hline 4 & 10 & 30 & 60 \\
\hline 5 & 15 & 30 & 55 \\
\hline 6 & 15 & 35 & 50 \\
\hline 7 & 18 & 28 & 54 \\
\hline 8 & 20 & 25 & 55 \\
\hline 9 & 20 & 30 & 50 \\
\hline 10 & 22 & 32 & 46 \\
\hline
\end{tabular}

All of the samples listed in Table 2 were analyzed by XRD to determine the type of crystals, if any, that were present in the glass. Two samples (numbers 7 and 10) contained trace amounts of crystals. Since crystallization can affect the durability of the glass, all ten of the glass samples were subjected to the Product Consistency Test (PCT). The PCT is a crushed glass leach test that measures the releases of several elements from the glass. The test is performed in $90^{\circ} \mathrm{C}$ deionized water for seven days. Each sample was performed in triplicate and each test included the appropriate blanks and standards. The results of the standards and blanks indicated that the tests were acceptable.

The average releases of several elements were used along with the composition of the glass to calculated the average normalized release for boron, sodium and lithium. Table 3 presents the normalized PCT results for the glasses listed in Table 2, along with the accepted values for the Environmental Assessment (EA) glass. ${ }^{5}$ The HLW acceptance criteria states that any glass produced must be at least two standard deviations below the results for the EA glass in order to be considered acceptable. Therefore, all of these glasses can be considered durable. The results shown in Table 3 also indicate that the crystals detected in the two samples did not affect the glass durability. 
Table 3 - PCT Results (in g/L) during Scoping Studies

\begin{tabular}{|c|c|c|c|}
\hline Sample & $\mathrm{B}$ & $\mathrm{Na}$ & $\mathrm{Li}$ \\
\hline \hline 1 & 1.29 & 1.21 & 1.27 \\
\hline 2 & 1.30 & 1.33 & 1.26 \\
\hline 3 & 0.88 & 0.85 & 0.94 \\
\hline 4 & 0.86 & 0.85 & 0.97 \\
\hline 5 & 0.82 & 0.86 & 0.94 \\
\hline 6 & 0.86 & 0.91 & 0.93 \\
\hline 7 & 0.33 & 0.17 & 0.61 \\
\hline 8 & 0.50 & 0.43 & 0.70 \\
\hline 9 & 0.37 & 0.15 & 0.82 \\
\hline 10 & 0.55 & 0.62 & 0.67 \\
\hline $\mathrm{EA}^{5}$ & 16.7 & 13.3 & 9.6 \\
\hline
\end{tabular}

\section{Screening Experiments}

A Plackett-Burman ${ }^{6}$ screening designed experiment was performed in an attempt to increase the CST loadings. Initially, twelve compositions were tested at $28 \mathrm{wt} \%$ sludge oxides and $20 \mathrm{wt} \%$ CST. Six of these samples were amorphous after air quenching, so the CST loading of these samples was increased to $30 \mathrm{wt} \%$ CST. Five of the samples visually did not contain crystals, so these samples were vitrified with $40 \mathrm{wt} \% \mathrm{CST}$. It was then determined based on cesium loading data that CST loadings above $20 \mathrm{wt} \%$ may not be reasonable from an economic basis. The five compositions that were amorphous at 30 wt\% CST loadings were the samples subjected to the DWPF canister centerline cooling.

Since crystallization tends to occur during cooling and since the cooling rate at the DWPF canister centerline has been determined to be the slowest cooling rate (and thus, the most conservative), this rate was used for several glasses with various CST loadings. Table 4 presents the waste loadings of the samples tested, along with the crystallization data for each sample. The crystallization data in Table 4 is based on visual observation. XRD was performed on those samples that contained no visual crystals. Small amounts of spinel crystals were detected by XRD in all of the samples indicated in Table 4 to be non-crystallized, but the amount of crystallization was not enough to be considered significant. 
Table 4 - Crystallization Results for Centerline Cooled Glasses

\begin{tabular}{|c|c|c|}
\hline Composition & CST wi\% & Crystallized? \\
\hline \hline 3 & 5 & No \\
\hline 3 & 10 & No \\
\hline 4 & 5 & Partially \\
\hline 4 & 10 & Yes \\
\hline 4 & 20 & Yes \\
\hline 9 & 5 & No \\
\hline 9 & 10 & No \\
\hline 9 & 20 & Yes \\
\hline 11 & 5 & No \\
\hline 11 & 10 & No \\
\hline 11 & 15 & No \\
\hline 12 & 10 & Yes \\
\hline
\end{tabular}

\section{Final Determination Studies}

A series of experiments were performed to determined the actual glass formers that would be used in the radioactive demonstration. These experiments began with the composition number 11 since it did not contain significant crystallization, as determined by XRD analysis, at CST loadings between 5 and $15 \mathrm{wt} \%$.

The composition of the unloaded CST was compared to composition of the loaded CST. The loaded CST contained more sodium and potassium because it was pretreated with sodium hydroxide. The loaded CST also contained cesium and small amounts of strontium, but these were at levels that were not expected to affect glass quality. Because the loaded CST contained more sodium, two new compositions were tested along with composition 11. The three compositions were vitrified using pretreated, but unloaded CST.

In addition, the composition of the nonradioactive sludge was compared to the composition of the radioactive Tank 51 sludge. Table 5 lists the major elements present in the radioactive sludge. The main difference between the radioactive and nonradioactive elemental compositions is that the radioactive sludge contained uranium. The radioactive sludge also contained higher nitric acid concentrations than the nonradioactive sludge. Therefore, equivalent concentrations of nitric acid were added to the nonradioactive sludge prior to vitrification to determine if problems would occur with processing. "All three compositions were then vitrified with the acidified nonradioactive sludge. 
Table 5 - Major Elemental Composition of Radioactive DWPF Sludge

\begin{tabular}{|c|c|}
\hline Element & Weight \% \\
\hline \hline $\mathrm{Al}$ & 6.62 \\
\hline $\mathrm{Ca}$ & 2.43 \\
\hline $\mathrm{Fe}$ & 25.0 \\
\hline $\mathrm{Mg}$ & 1.19 \\
\hline $\mathrm{Mn}$ & 2.63 \\
\hline $\mathrm{Na}$ & 7.17 \\
\hline $\mathrm{Si}$ & 1.14 \\
\hline $\mathrm{U}$ & 3.24 \\
\hline
\end{tabular}

Three samples of each of the three compositions were melted at $1150^{\circ} \mathrm{C}$. The first sample was poured, the second was air quenched and the third was slowly cooled. The results indicated that composition 11 with the pretreated, unloaded CST, and acidified nonradioactive sludge was within the required viscosity range when poured and did not form crystals upon slow cooling as measured by XRD.

\section{Radioactive Demonstration}

Based on the results of the nonradioactive glass formulation development work, a waste loading of $28 \mathrm{wt} \%$ sludge oxides and $5 \mathrm{wt} \%$ CST was chosen for the radioactive demonstration. The radioactive demonstration used actual sludge from SRS Tank 51 (the composition is given in Table 5), along with Cs-loaded CST from a demonstration at the Oak Ridge National Laboratory. The appropriate glass forming chemicals were thoroughly combined with the radioactive sludge and CST, poured into a platinum crucible, and then vitrified in a muffle furnace.

After approximately four hours at the melt temperature, the crucible was removed from the muffle furnace and poured into a stainless steel pan. There were no visible differences between the radioactive and nonradioactive glasses. The glass poured easily from the crucible and was in the same viscosity range as the nonradioactive glass sample, indicating that it would be acceptable in the DWPF melter.

\section{Conclusions}

A glass formulation was developed using nonradioactive sludge and unloaded CST. The resulting glass was more durable than the HLW EA glass, thus meeting the product specifications of the Waste Acceptance Product Specifications (WAPS). The glass also had viscosity and liquidus properties within the acceptable processing ranges. The radioactive demonstration of this formulation using Tank 51 sludge and Cs-loaded CST successfully incorporated $28 \mathrm{wt} \%$ sludge oxides and $5 \mathrm{wt} \%$ CST. 
E. W. Holtzscheiter

7

WSRC-TR-97-00312

References

1. R. Braun et al, "Crystalline Silicotitanate - Novel Commercial Cesium Ion Exchangers", Spectrum '96, Proceedings - International Topical Meeting on Nuclear and Hazardous Waste Management, (1996).

2. M. K. Andrews and J. R. Harbour, "Glass Formulation Requirements for DWPF Coupled Operations using Crystalline Silicotitanates (U)", WSRC-TR-97-0004, (1997).

3. R. E. Edwards, "SGM Run 8 - Canister and Glass Temperatures During Filling and Cooldown", DPST-87-801, (1987).

4. ASTM Procedure, C-1286-94, "Determining Chemical Durability of Nuclear Waste Glasses: The Product Consistency Test (PCT)".

5. U. S. Department of Energy, "Environmental Assessment Waste Form Selection for SRP High-Level Waste", USDOE Report DOE-EA-0179, (1982).

6. G. E. P. Box, W. G. Hunter and J. S. Hunter, Statistics for Experiments, John Wiley and Sons, New York (1978).

60 


\section{Attachment 8 .}

M. K. Andrews and J. R. Harbour, "Glass Formulation Requirements for Hanford Coupled Operations Using Crystalline Silicotitanate (CST) (U)," WSRC-RP-97-0265, (1997). 
WSRC-RP-97-0265

\title{
GLASS FORMULATION REQUIREMENTS FOR HANFORD COUPLED OPERATIONS USING CRYSTALLINE SILICOTITANATES (CST) (U)
}

\author{
M. K. Andrews and J. R. Harbour \\ Westinghouse Savannah River Company \\ Aiken, S. C. 29808
}

\section{INTRODUCTION}

The U.S. Department of Energy (DOE) through the Richland Operations Office has requested proposals from the private sector for the treatment of waste from the Hanford Waste Tanks. Phase I of this privatization initiative may include a demonstration for treatment and immobilization of both low activity and high-level waste. If the demonstration includes high-level waste, then the Cs-137 waste stream most likely will be combined with the high-level waste sludge to produce a coupled feed for immobilization (most likely vitrification using a borosilicate glass). It appears that pretreatment will involve the removal of cesium (and perhaps strontium and some transuranic radionuclides) from the supernate using an ion exchange material such as crystalline silicotitanate (CST). The ion exchange sorbent (or the eluted Cs-137) can then be combined with the sludge and vitrified in a coupled operation similar to the DWPF process. Alternatively, the cesium-loaded ion exchange sorbent can be vitrified pairectly to produce a separate glass waste form.

SRTC has been involved in an Office of Science and Technology (EM-50). funded project to determine if Cs-137 loaded CST can be successfully incorporated into glass at significant levels. ${ }^{1}$ For a waste form which would include only Cs-137 loaded CST, concentrations up to $60 \mathrm{wt} \%$ of CST in glass have been achieved. ${ }^{2}$ The glass produced from this demonstration is both processable and durable. This CST-only waste form could be used at Hanford if the cesium-loaded CST is vitrified in a separate melter. For coupled feed operations, the CST would be mixed with high-level radioactive sludge from the Hanford tanks. This report provides the basis and the path forward for SRTC's efforts at developing a glass frit formulation which will incorporate both Hanford sludge and cesium-loaded CST for a coupled flowsheet. The goal of this work is to demonstrate the feasibility of vitrification as a method for immobilization of coupled feed (specifically, Cs-137-loaded CST). A separate report ${ }^{3}$ has been issued which details the basis and the path forward for the glass formulation efforts for the coupling of DWPF sludge with CST. 


\section{HANFORD TANK WASTE}

Hanford has 177 double and single shell waste tanks which, like the tanks at SRS, contain sludge, salt cake, and supernate. There are a number of types of tank waste at Hanford including Neutralized Current Acid Waste (NCAW), Double Shell Slurry Feed (DSSF), and Single Shell Tanks (SST) waste. The Phase 1 demonstration may immobilize 3 to 6 percent of the High-level waste over a period of 5 to 9 years. ${ }^{4}$

Sludge and Sludge Surrogate. Currently, the High-Level waste demonstration of Phase 1 will treat and immobilize waste from four tanks: 241-AZ-101, 241-AZ-102, 241-AY102, and 241-C-106. ${ }^{4}$ Two of these tanks, 241-AZ-101 and 241-AZ-102, contain 161,000 liters $(267,000 \mathrm{~kg})$ and 333,000 liters $(496,000 \mathrm{~kg})$, respectively, of NCAW waste. Tank 241-AY-102 contains 121,00 liters of sludge $(170,000 \mathrm{~kg})$ and Tank $241-\mathrm{C}-$ 106 contains 745,000 liters of sludge $(1,066,000 \mathrm{~kg})$. All of these sludges are slurries diluted by $50 \%$ water.

It has yet to be determined how the waste from these four tanks will be treated. The tanks could be treated separately, blended, or partially blended. The sludge in these tanks most likely will be water-washed but may also be caustic-washed. The caustic wash removes aluminum plus some other non-waste components from the waste.

In order to develop a glass frit formulation for the coupled feed, it is first necessary to define the composition of the sludge which will be used. Lambert, Stegen, and Vienna ${ }^{4}$ have provided a nominal blend composition for the four tanks of Phase 1 after both water and caustic washing. This blended average (with caustic wash) has been selected as the sludge composition for this work and is provided in Table 1.

Table 1. Elemental Composition of Hanford Blended Average

\begin{tabular}{|c|c|}
\hline Element & wt\% \\
\hline \hline $\mathrm{Ag}$ & 0.154 \\
\hline $\mathrm{Al}$ & 5.931 \\
\hline $\mathrm{B}$ & 0.061 \\
\hline $\mathrm{Ba}$ & 0.634 \\
\hline $\mathrm{Ca}$ & 1.726 \\
\hline $\mathrm{Ce}$ & 1.313 \\
\hline $\mathrm{Cl}$ & 0.031 \\
\hline $\mathrm{Co}$ & 0.160 \\
\hline $\mathrm{Cr}$ & 0.268 \\
\hline
\end{tabular}

\begin{tabular}{|c|c|}
\hline Element & wt \% \\
\hline $\mathrm{F}$ & 0.165 \\
\hline $\mathrm{Fe}$ & 20.412 \\
\hline $\mathrm{K}$ & 0.637 \\
\hline $\mathrm{La}$ & 0.519 \\
\hline $\mathrm{Mg}$ & 0.861 \\
\hline $\mathrm{Mn}$ & 0.599 \\
\hline $\mathrm{Na}$ & 16.913 \\
\hline $\mathrm{Nd}$ & 0.404 \\
\hline $\mathrm{Ni}$ & 0.956 \\
\hline
\end{tabular}

\begin{tabular}{|c|c|}
\hline Element & wt\% \\
\hline $\mathrm{P}$ & 0.180 \\
\hline $\mathrm{Pb}$ & 0.371 \\
\hline $\mathrm{Ru}$ & 0.167 \\
\hline $\mathrm{Se}$ & 0.168 \\
\hline $\mathrm{Si}$ & 8.718 \\
\hline $\mathrm{SO} 4$ & 0.843 \\
\hline $\mathrm{Sr}$ & 0.061 \\
\hline $\mathrm{Zr}$ & 3.398 \\
\hline
\end{tabular}

The batch sheet for the sludge surrogate which was developed from the blended average is shown in Table 2. 
Table 2. Sludge Surrogate Developed from the Blended Average

\begin{tabular}{|c|c|}
\hline Compound & Amount (g) \\
\hline $\mathrm{Al}_{2} \mathrm{O}_{3}$ & 9.102 \\
\hline $\mathrm{AgNO}_{3}$ & 0.197 \\
\hline $\mathrm{Na}_{2} \mathrm{~B}_{4} \mathrm{O}_{7}$ & 0.437 \\
\hline $\mathrm{BaCO}_{3}$ & 0.740 \\
\hline $\mathrm{CaCO}_{3}$ & 3.501 \\
\hline $\mathrm{Ce}\left(\mathrm{NO}_{3}\right)_{3} \cdot 6 \mathrm{H}_{2} \mathrm{O}$ & 3.305 \\
\hline $\mathrm{Co}\left(\mathrm{NO}_{3}\right)_{2} \cdot 6 \mathrm{H}_{2} \mathrm{O}$ & 0.642 \\
\hline $\mathrm{K}_{2} \mathrm{CrO}_{4}$ & 0.813 \\
\hline $\mathrm{Fe}_{2} \mathrm{O}_{3}$ & 23.701 \\
\hline $\mathrm{KNO}_{3}$ & 0.491 \\
\hline $\mathrm{La}_{2} \mathrm{O}_{3}$ & 0.494 \\
\hline $\mathrm{MgO}$ & 1.160 \\
\hline $\mathrm{MnO}_{2}$ & 0.770 \\
\hline
\end{tabular}

\begin{tabular}{|c|c|}
\hline Compound & Amount (g) \\
\hline $\mathrm{Na}_{2} \mathrm{CO}_{3}$ & 31.169 \\
\hline $\mathrm{Nd}_{2} \mathrm{O}_{3}$ & 0.383 \\
\hline $\mathrm{NiCO}_{3}$ & 0.716 \\
\hline $\mathrm{P}_{2} \mathrm{O}_{5}$ & 0.413 \\
\hline $\mathrm{PbO}$ & 0.325 \\
\hline $\mathrm{RuCl}_{3} \cdot 2 \mathrm{H}_{2} \mathrm{O}$ & 0.325 \\
\hline $\mathrm{Se}$ & 0.136 \\
\hline $\mathrm{SiO}$ & 15.147 \\
\hline $\mathrm{Sr}\left(\mathrm{NO}_{3}\right)_{2}$ & 0.120 \\
\hline $\mathrm{ZrO}_{2}$ & 3.728 \\
\hline $\mathrm{NaF}$ & 0.296 \\
\hline $\mathrm{NiSO}_{4} \cdot 6 \mathrm{H}_{2} \mathrm{O}$ & 1.892 \\
\hline
\end{tabular}

Supernate. The NCAW, DSSF, and SST supernates have different chemical compositions and amounts of Cs-137. The NCAW supernate contains relatively high amounts of Cs-137 whereas the DSSF and SST tanks contain significantly less Cs-137. The sodium, potassium, and Cs-137 concentrations in Hanford NCAW, DSSF, and SST waste ${ }^{5}$ are provided in Table 3, along with information from SRS and Oak Ridge MVST tanks for comparison.

Table 3. Cs-137, Na, and K Concentrations in Hanford NCAW, DSSF, and SST Waste, SRS and ORNL MVST Wastes

\begin{tabular}{|c||c|c|c|c|c|}
\hline & $\begin{array}{c}\text { Cs-137 } \\
(\mathbf{m g} / \mathbf{L})\end{array}$ & $\begin{array}{c}\text { Cs-137 } \\
\text { Curies }\end{array}$ & $\begin{array}{c}\text { Na } \\
\text { (molar) }\end{array}$ & $\begin{array}{c}\text { K } \\
\text { (molar) }\end{array}$ & $\begin{array}{c}\text { VOLUME } \\
\text { (liters) }\end{array}$ \\
\hline \hline SRS & 20 & $2.5 \mathrm{E}+08$ & 14 & 0.1 & $1.1 \mathrm{E}+08$ \\
\hline $\begin{array}{c}\text { Hanford } \\
\text { NCAW }\end{array}$ & 25 & $1.3 \mathrm{E}+07$ & 5 & 0.1 & $6.7 \mathrm{E}+06$ \\
\hline Hanford DSSF & 4 & $1.3 \mathrm{E}+07$ & 8.5 & 0.8 & $4.9 \mathrm{E}+07$ \\
\hline Hanford SST & 0.5 & $1.8 \mathrm{E}+07$ & 5 & $* *$ & $4.5 \mathrm{E}+08$ \\
\hline ORNL MVST & 0.15 & $1.4 \mathrm{E}+04$ & 4.1 & 0.4 & $7.5 \mathrm{E}+05$ \\
\hline
\end{tabular}

* Includes supernate and saltcake ** Data not available

An alternate approach to characterizing the Hanford supernate is to define a blend of all waste supernate (including dissolved saltcake). This has been done by Kurath et $\mathrm{al}^{6}$ and their report provides data on this average supernate obtained by blending the supernate from all the tanks at Hanford and normalizing to $5 \mathrm{M}$ sodium. According to this report, there will be 674 million liters of supernate with $47 \mathrm{Ci} / \mathrm{m}^{3}$ of Cs-137. This translates to a total of 32 million $\mathrm{Ci}$ of $\mathrm{Cs}-137$ in the supernate. The blended supernate contains a potassium concentration of $0.027 \mathrm{M}$ and a sodium concentration of $5 \mathrm{M}$. There are 2.8 $\mathrm{C} i / \mathrm{m}^{3}$ of $\mathrm{Sr}-90$. 


\section{AMOUNT OF CST REQUIRED}

Calculations have been performed by M. E. Johnson of TWRS Systems Engineering to determine the amount of CST required to treat the supernate in Hanford NCAW, DSSF, and SST tanks. A summary of the calculations is provided in Table 4. These calculations assumed a multiple batch, counter-current process and a requirement to reduce the final cesium concentration to less than the Class A limit of $1 \mathrm{Ci} / \mathrm{m}^{3}$. Since the limit for the final cesium concentration has not been established, the calculations in Table 4 could change significantly. For instance, the Class C limit of $4600 \mathrm{Ci} / \mathrm{m}^{3}$ would dramatically reduce the amount of CST required. However, restricting the final cesium concentration to 0.1 of the Class A limit, would significantly increase the amount of CST necessary. ${ }^{5}$

Table 4. Amount of supernate present in Hanford Tanks and the estimated amount of CST required to treat this supernate (from Michael E. Johnson, TWRS Systems Engineering)

\begin{tabular}{|c|c|c|c|c|c|c|}
\hline & \begin{tabular}{|c|} 
Volume \\
liters \\
\end{tabular} & $\begin{array}{c}\text { Cs-137 } \\
\mathrm{Ci} \\
\end{array}$ & $\begin{array}{c}\text { Cs-137 } \\
\text { kg } \\
\end{array}$ & $\begin{array}{c}\text { CST Req'd } \\
\mathrm{kg} \\
\end{array}$ & $\begin{array}{c}\text { Cs-137 } \\
\text { Loading } \\
\text { Ci/g CST } \\
\end{array}$ & $\begin{array}{c}\text { Cs-137 } \\
\text { Loading } \\
\text { wt\% }\end{array}$ \\
\hline NCAW & $6.70 \mathrm{E}+06$ & $1.26 \mathrm{E}+07$ & 145 & $5.00 \mathrm{E}+04$ & 0.252 & 0.29 \\
\hline$\overline{\mathrm{DSSF}}$ & $4.90 \mathrm{E}+07$ & $1.29 \mathrm{E}+07$ & 148 & $4.50 \mathrm{E}+05$ & 0.029 & 0.033 \\
\hline SST & $4.50 \mathrm{E}+08$ & $1.75 \mathrm{E}+07$ & 201 & $1.24 \mathrm{E}+06$ & 0.014 & 0.016 \\
\hline
\end{tabular}

The total amount of CST required to treat the supernates in the NCAW, DSSF, and SST is $1.74 \times 10^{6} \mathrm{~kg}$. However, the amount of CST required depends significantly on the composition, in addition to the amount, of supernate.

Using SRS simulated salt solutions, McCabe showed that the Cs-137 loading on CST is dependent upon the cesium, sodium and potassium concentrations in the supernate. ${ }^{7}$ For fixed sodium ard poiassium levels, McCabe demonstrated a range of 1.2 to $4.6 \mathrm{wt} \%$ cesium sorption on powdered CST depending upon the cesium concentration in solution. For the cesium in the DWPF supernate, which contains 38 atom\% Cs-137, these values correspond to 0.5 to $1.8 \mathrm{wt} \% \mathrm{Cs}-137$ sorption on the CST. Comparison of these values to the Cs-137 loadings listed in Table 4 shows that only the NCAW approaches the DWPF range.

One explanation for the difference in Cs-137 loadings between the Hanford and DWPF supernates is the difference in composition. It has been shown that higher concentrations of potassium lead to less cesium sorption. ${ }^{8}$ At $5 \mathrm{M}$ sodium, the Hanford blended supernate is $0.027 \mathrm{M}$ potassium, and the SRS simulant supernate is $0.015 \mathrm{M}$ potassium. In addition, the cesium concentration in the average Hanford supernate is only $3 \mathrm{mg} / \mathrm{L}$, compared to the lowest tested values of $28 \mathrm{mg} / \mathrm{L}$ for the SRS supernate. Extrapolation of McCabe's data to the Hanford level of cesium, indicates $\sim 0.02$ wt\% sorption of Cs-137, which is close to the values for the DSSF and SST supernates (0.033 and 0.016.wt\% respectively). 
For the NCAW supernate, the cesium concentration is $25 \mathrm{mg} / \mathrm{L} \mathrm{Cs}-137$, which is only slightly less than that tested by McCabe $(28 \mathrm{mg} / \mathrm{L})$. However, the NCAW. supernate has a higher potassium level $(0.1 \mathrm{M})$ than the tested DWPF simulant which contained $0.015 \mathrm{M}$ potassium. This would explain the lower Cs-137 capacity calculated for the NCAW waste $(0.29 \mathrm{wt} \%$ compared to $0.5 \mathrm{wt} \%$ for DWPF).

Although there is uncertainty in calculating the amount of CST that will be required to treat all of the Hanford supernate, the values in Table 4 represent good estimates based on the results of McCabe on DWPF simulated supernate.

\section{CST LOADING IN THE GLASS}

The total amount of glass which will be produced to treat all of the Hanford sludge has been estimated at $2.28 \times 10^{7} \mathrm{~kg}$ for a $45 \mathrm{wt} \%$ waste oxide loading. The total amount of CST required to treat all of the Hanford Tank supernates is $1.74 \times 10^{6} \mathrm{~kg}$. Therefore, a balanced CST/sludge feed would require, with no increase in the amount of glass or canisters produced, a $7.6 \mathrm{wt} \%$ loading of CST in glass.

The goal is to develop a glass frit formulation which will incorporate $\sim 45$ wt $\%$ sludge waste oxides and $\sim 7.6 \mathrm{wt} \% \mathrm{Cs}-137$ loaded CST. This would maintain the glass production at $\sim 2.28 \times 10^{7} \mathrm{~kg}$ of glass.

\section{PATH FORWARD}

A sludge surrogate has been developed based on a blended average of the four tanks which will be used during Phase 1 of the privatization process. For the entire tank waste treatment, a coupled feed (with balanced sludge and CST) containing $7.6 \mathrm{wt} \%$ CST has been estimated. For this work, the uncertainties around these estimates will be taken into account by attempting to develop a frit formulation(s) which can incorporate between 5 and $15 \mathrm{wt} \% \mathrm{CST}$ while maintaining as high a level as possible of the sludge surrogate (roughly 45 wt $\%$ oxide loading).

\section{REFERENCES}

1. D. M. Ferrara, Immobilization of IX Resins (CST), WSRC Immobilization, TTP SR16WT31, Waste Tanks Immobilization, Task Number B, October, 1996.

2. M. K. Andrews and J. R. Harbour, Effect of CST Ion Exchange Loading on the Volume of Glass Produced During the Vitrification Demonstration at SRTC (U), WSRC-TR-96-0372, Rev. 0, November, 1996.

3. M. K. Andrews and J. R. Harbour, Glass Formulation Requirements for DWPF Coupled Operations Using Crystalline Silicotitanates (U), WSRC-TR-970004, January, 1997.

4. S. L. Lambert, G. E. Steger, and J. D. Vienna, Tank Waste Remediation System Phase 1 High-Level Waste Feed Processability Assessment Report, WHC-SDWD-TI-768, Rev. 0, August, 1996.

5. R. S. Goheen and D. E. Kurath, Conceptual Study of In-Tank Cesium Removal Using an Inorganic Ion Exchange Material, PNNL-11114, March, 1994. 
6. D. E. Kurath, K..P. Brooks, G. W. Hollenberg, R. Clemmer, S. Balagopal, T. Landro, and D. P. Sutija, Preconceptual Design of a Salt Splitting Process Using Ceramic Membranes, PNNL-11454, UC-2030, January, 1997.

7. D. J. McCabe, Crystalline Silicotitanate Examination Results (U), WSRC-RP94-1123, May, 1995.

8. R. Braun, T. J. Dangieri, D. J. Fennelly, J. D. Sherman, W. C. Schwerin, R. R. Willis, et al, Crystalline Silicotitanates-Novel Commercial Cesium Ion Exchangers, Spectrum ‘96, Seattle, Washington, August 1996.

\section{DISTRIBUTION}

M. K. Andrews, 773-A

N. E. Bibler, 773-A

D. A. Crowley, 773-43A

E. F. Duhn, 773-A

T. L. Fellinger, 773-A

D. M. Ferrara, 773-43A

J. R. Harbour, 773-43A

E. W. Holtzscheiter, 773-A

L. F. Landon, 704-1T

D. J. McCabe, 773-43A

L. M. Papouchado, 773-A

C. T. Randall, 704-T 